\title{
Meta-Analysis and Structural Dynamics of the Emergence of Genetic Variants of SARS-CoV-2
}

\section{Nicolas Castonguay ${ }^{1}$, Wandong Zhang $^{2,3}$ and Marc-Andre Langlois ${ }^{1,4^{*}}$}

${ }^{1}$ Department of Biochemistry, Microbiology \& Immunology, Faculty of Medicine, University of Ottawa, Ontario, Canada K1H 8M5.

${ }^{2}$ Department of Cellular \& Molecular Medicine, Faculty of Medicine, University of Ottawa, Ontario, Canada K1H 8M5.

${ }^{3}$ Human Health Therapeutics Research Centre, National Research Council Canada, Ottawa, Canada K1A 0R6

${ }^{4} \mathrm{uOttawa}$ Center for Infection, Immunity and Inflammation (CI3).

Running title: Genome Evolution of SARS-CoV-2.

*Correspondence should be addressed to: langlois@uottawa.ca

Key words: SARS-CoV-2, COVID-19, Variants of concern, B.1.1.7, B1.351, P.1, D614G 
medRxiv preprint doi: https://doi.org/10.1101/2021.03.06.21252994; this version posted May 15, 2021. The copyright holder for this preprint

(which was not certified by peer review) is the author/funder, who has granted medRxiv a license to display the preprint in perpetuity.

It is made available under a CC-BY 4.0 International license .

Castonguay et al., $2021 \quad$ Genome Evolution of SARS-CoV-2

\begin{abstract}
The novel Severe Acute Respiratory Syndrome Coronavirus 2 (SARS-CoV-2) emerged in late December 2019 in Wuhan, China, and is the causative agent for the worldwide COVID-19 pandemic. SARS-CoV-2 is a positive-sense single-stranded RNA virus belonging to the betacoronavirus genus. Due to the errorprone nature of the viral RNA-dependent polymerase complex, coronaviruses are known to acquire new mutations at each cycle of genome replication. This constitutes one of the main factors driving the evolution of its relatively large genome and the emergence of new genetic variants. In the past few months, the identification of new B.1.1.7 (UK), B.1.351 (South Africa) and P.1 (Brazil) variants of concern (VOC) have highlighted the importance of tracking the emergence of mutations in the SARS-CoV-2 genome that impact transmissibility, virulence, and immune and neutralizing antibody escape. Here we analyzed the appearance and prevalence trajectory over time of mutations that appeared in all SARS-CoV-2 genes from December, 2019 to April, 2021. The goal of the study was to identify which genetic modifications are the most frequent and study the dynamics of their propagation, their incorporation into the consensus sequence, and their impact on virus biology. We also analyzed the structural properties of the spike glycoprotein of the B.1.1.7, B.1.351 and P.1 variants for its binding to the host receptor ACE2. This study offers an integrative view of the emergence, disappearance, and consensus sequence integration of successful mutations that constitute new SARS-CoV-2 variants and their impact on neutralizing antibody therapeutics and vaccines.
\end{abstract}


medRxiv preprint doi: https://doi.org/10.1101/2021.03.06.21252994; this version posted May 15, 2021. The copyright holder for this preprint (which was not certified by peer review) is the author/funder, who has granted medRxiv a license to display the preprint in perpetuity.

Castonguay et al., 2021

Genome Evolution of SARS-CoV-2

\section{IMPORTANCE}

SARS-CoV-2 is the etiological agent of COVID-19, which has caused $>3.4$ million deaths worldwide as of April, 2021. Mutations occur in the genome of SARS-CoV-2 during viral replication and affect viral infectivity, transmissibility, and virulence. In early March 2020, the D614G mutation in the spike protein emerged, which increased viral transmissibility and is now found in over $90 \%$ of all SARS-CoV-2 genomic sequences in GISAID database. Between October and December 2020, B.1.1.7 (UK), B.1.351 (South Africa) and P.1 (Brazil) variants of concern (VOCs) emerged, which have increased neutralizing antibody escape capabilities because of mutations in the receptor binding domain of the spike protein. Characterizing mutations in these variants is crucial because of their effect on adaptive immune responses, neutralizing antibody therapy, and their impact on vaccine efficacy. Here we tracked and analyzed mutations in SARSCoV-2 genes since the beginning of the pandemic and investigated their functional impact on the spike of these three VOCs. 
medRxiv preprint doi: https://doi.org/10.1101/2021.03.06.21252994; this version posted May 15, 2021. The copyright holder for this preprint (which was not certified by peer review) is the author/funder, who has granted medRxiv a license to display the preprint in perpetuity. It is made available under a CC-BY 4.0 International license.

Castonguay et al., 2021

Genome Evolution of SARS-CoV-2

\section{Graphical Abstract}

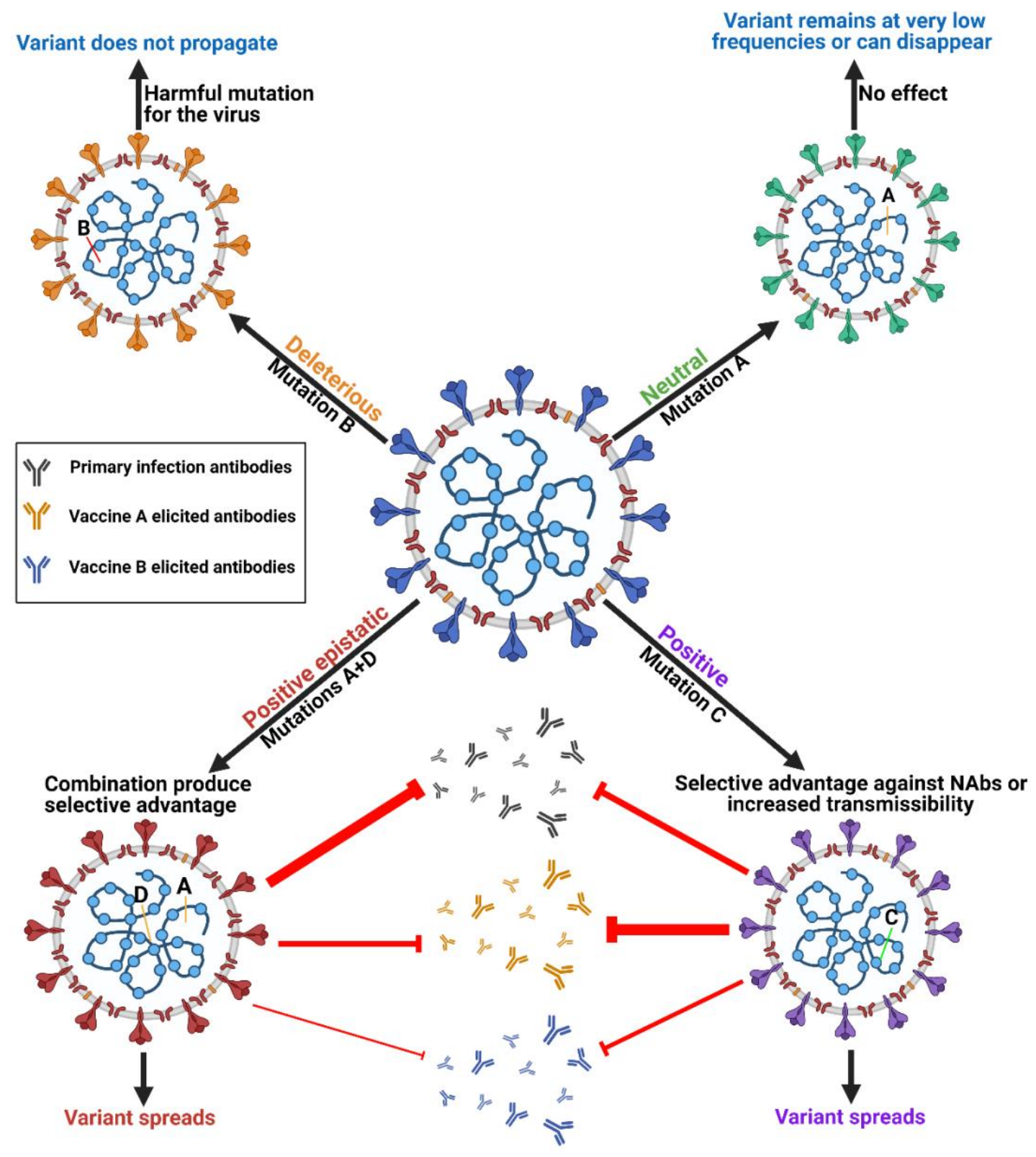


medRxiv preprint doi: https://doi.org/10.1101/2021.03.06.21252994; this version posted May 15, 2021. The copyright holder for this preprint

(which was not certified by peer review) is the author/funder, who has granted medRxiv a license to display the preprint in perpetuity. It is made available under a CC-BY 4.0 International license .

Castonguay et al., 2021

Genome Evolution of SARS-CoV-2

\section{INTRODUCTION}

In late December 2019, a new betacoronavirus known as Severe Acute Respiratory Syndrome Coronavirus 2 (SARS-COV-2) emerged in the city of Wuhan in the province of Hubei, China (1). SARS-CoV-2 is the etiological viral agent for the worldwide COVID-19 pandemic resulting in more than 162 million infected and 3.4 million deaths worldwide as of April, 2021 (2,3). SARS-CoV-2 is an enveloped, positive-sense single-stranded RNA (+ssRNA) virus with a genome length of 29,811 nucleotides (4). The mutation rates of RNA viruses are generally higher than that of DNA viruses because of the low fidelity of their viral RNA polymerases $(5,6)$. Mutations occur when viral replication enzymes introduce errors in the viral genome resulting in the creation of premature termination codons, deletions and insertions of nucleotides that can alter open reading frames and result in amino acid substitutions in viral proteins. These mutations combined with the selective pressure of the human immune system lead to the selection and evolution of viral genomes $(6,7)$. However, coronaviruses are one of the few members of the RNA virus family that possess limited but measurable proofreading ability via the 3'-to 5'- exoribonuclease activity of the non-structural viral protein 14 (nsp14) (8,9). Coronaviruses are therefore expected to evolve through genetic drift much slower than other RNA viruses that do not have this ability, such as influenza viruses $(8,10)$. Additionally, SARSCoV-2 and other coronaviruses have low known occurrences of recombination between family members (i.e., genetic shift), and therefore are mostly susceptible to genetic drift (11).

SARS-CoV-2 has reached pandemic status due to its presence on every continent and has since maintained a high level of transmissibility across hosts of various ethnical and genetic backgrounds $(2,12)$. Moreover, SARS-CoV-2 infections have been reported to naturally infect minks, ferrets, cats, tiger, and dogs, which allows the virus to replicate in completely new hosts and mutate to produce new variants and possibly new strains (13,14). In March 2020, the now dominant D614G mutation first emerged in the spike protein (S) of SARS-CoV-2. The S protein is present as a trimer at the surface of the viral envelope and is responsible for attachment of the virus to the human angiotensin converting enzyme 2 (hACE2), the entry receptor for SARS-CoV-2 into human cells (15). Published evidence has now shown that D614G increases viral fitness, transmissibility and viral load but does not directly affect COVID-19 pathogenicity $(16,17,18,19)$. Additionally, emerging evidence indicates that D614G may have epistatic interactions that exacerbate the impact of several other independent mutations (19). Mutations in the S protein, and particularly in the receptor binding domain (RBD), are of very high concern given that they can directly influence viral infectivity, transmissibility, and resistance to neutralizing antibodies and $\mathrm{T}$ cell responses.

New mutations are frequently and regularly detected in the genome of SARS-CoV-2 through whole genome sequencing; however, very few of these mutations make it into the transmitted viral consensus sequence. The reference strain is generally regarded as the dominant transmitted strain at a given time. Its sequence 
medRxiv preprint doi: https://doi.org/10.1101/2021.03.06.21252994; this version posted May 15, 2021. The copyright holder for this preprint (which was not certified by peer review) is the author/funder, who has granted medRxiv a license to display the preprint in perpetuity.

Castonguay et al., 2021

Genome Evolution of SARS-CoV-2

is determined by aligning large numbers of recently sequenced genomes and establishing a consensus sequence composed of the highest frequency nucleotide for each position in the viral genome. A genetic variant is a version of the reference strain that has acquire one or several new mutations and acts as the founder for further genetic diversification and evolution. Mutations arise regularly in the reference strain, but few are longitudinally conserved. Genetic variants are therefore the rare successful offshoots of the reference strain.

Some variants rise rapidly in frequency and then collapse and disappear, while others will rise and overtake the frequency of the reference strain and become the new reference. There are three main genetic variants that have emerged in the past few months with sustained upward frequency trajectories. The first is the UK variant, also known as B.1.1.7/501Y.V1 (B1.1.7). It was first detected in September 2020 and is now present worldwide and poised to become the new reference strain $(20,21)$. The South African variant, also known as B.1.351/501Y.V2 (B.1.351), was first reported in October 2020 and is now increasing in prevalence in South Africa, Europe, and North America (21,22). The Brazilian variant, P.1/501Y.V3 (P.1), was first detected in travelers from Brazil that landed in Japan in January 2021 (23). It has since been identified in $42 \%$ of specimens in the Amazonian city of Manaus and in the U.S. at the end of January 2021 (23). These three variants are associated with increased resistance to neutralizing antibodies (Nabs) and all possess the N501Y mutation, which is a mutation in the RBD that is critical for the spike protein to interact with hACE2 $(24,25,26)$. This mutation is reported to cause increased resistance to Nabs, increased transmissibility, and increased virulence in animal models (27). In addition to the N501Y mutation, both the South African and Brazil variants possesses RBD mutations K417N(T) and E484K, which are also associated with further increased Nabs escape capabilities $(24,25)$.

Here we present a retrospective metadata analysis of mutations throughout the SARS-CoV-2 genome that reached at least a 1\% worldwide frequency between December 2019 and January 2021. We specifically investigated their frequency trajectory over time and their fixation into the reference sequencing using the Global Initiative on Sharing Avian Influenza Data (GISAID) (28). Additionally, we analyzed mutations in the $\mathrm{S}$ protein of the B.1.1.7, B.1.351 and P.1 variants and illustrated their impact on molecular interactions between the S protein and hACE2 and their potential impact on Nabs. 
medRxiv preprint doi: https://doi.org/10.1101/2021.03.06.21252994; this version posted May 15, 2021. The copyright holder for this preprint (which was not certified by peer review) is the author/funder, who has granted medRxiv a license to display the preprint in perpetuity.

Castonguay et al., 2021

Genome Evolution of SARS-CoV-2

\section{MATERIALS AND METHODS}

\section{Data collection and mutational analysis}

Genomes uploaded to the GISAID EpiCoV ${ }^{\mathrm{TM}}$ server database were analyzed from December $1^{\text {st }}, 2019$, to December $31^{\text {st }}, 2020$, and selected viral sequences with submission dates from December $1^{\text {st }}, 2019$ to January 6 , 2021. We first selected recurring mutations that were present in more than 500 reported genomes by August 2020, and another selection was made in January 2021 to capture recurring mutations present in more than 4000 reported genomes in GISAID. This strategy allowed us to study mutations reaching at least $1 \%$ in worldwide frequency. We filtered through 309,962 genomes for the analysis of selected mutations.

The worldwide frequency of the hCoV-19/Wuhan strain, and hCoV-19/D614G, B.1.1.7, B.1.351, and P.1 variants were analyzed from December $1^{\text {st }}, 2019$ to April $30^{\text {th }} 2021$. For the analysis of the mutations in B.1.1.7, B.1.351, and P.1 variants, we used the GISAID EpiCoV ${ }^{\mathrm{TM}}$ server database. Viral sequences on GISAID with submission dates between December $1^{\text {st }}, 2019$ and April 30 2021 were selected for the analysis. We filtered through 1,090,689 genomes for the analysis of the variants. Only complete SARS-CoV-2 genomes (28 to 30 Kbps) isolated from human hosts were analyzed. MUSCLE alignment tool on UGene, and SnapGene was used to determine the nucleotide mutations and codon changes of the non-synonymous and synonymous mutations by sequence alignments to the NCBI SARS-CoV-2 reference genome (NC_045512). All genomes uploaded to the GISAID database that were used in this study are presented in Supplementary Table 1. Graphs of mutations and variants were performed in RStudio with timelines, and genomes illustrations were produced in Biorender.

\section{Structural modeling}

Mutations in the spike protein in complex with hACE2 were analyzed using a mutagenesis tool for PyMOL (PDB: 7A94). Visualizations of mutations in the B.1.1.7, B.1.351 and P.1 variants were produced using the spike protein closed conformation (PDB: 6ZGE), interaction with hACE2 (PDB: 7A94), interaction with C102 $\mathrm{Nab}$ (PDB: 7K8M), and interaction with C121 Nab (PDB: 7K8X). Figures and rendering were prepared with PyMOL. 
medRxiv preprint doi: https://doi.org/10.1101/2021.03.06.21252994; this version posted May 15, 2021. The copyright holder for this preprint

(which was not certified by peer review) is the author/funder, who has granted medRxiv a license to display the preprint in perpetuity. It is made available under a CC-BY 4.0 International license.

Castonguay et al., 2021

Genome Evolution of SARS-CoV-2

\section{RESULTS}

Identification of emerging mutations in various SARS-CoV-2 genes. Emerging mutations in the SARSCoV-2 genome were investigated to illustrate the fluctuations of these mutations during a period of twelve months. We tracked genome mutations with a worldwide frequency greater than 1\% from December 2019 to December 31st, 2020 in the GISAID database. Genes NSP8, NSP10, NS6, NS7a, and E are not illustrated in Figure 1 given that they did not display mutations with frequencies sufficiently high to meet our inclusion criteria during the study period. This is indicative that these are some of the most conserved sequences of the SARS-CoV-2 genome. Viral proteins that have low mutation frequencies could be due to evolutionary constraints. Some of these viral proteins may be evolutionarily conserved and play important roles in virus assembly and stability, genome replication, and viral release from infected cells. Our analysis highlights the fixation of the D614G mutation in the S protein and that of the P323L mutation in the RNAdependent RNA polymerase (RdRp) (Fig.1). These are the only mutations to have successfully become part of the reference sequence as of December 2020. They appeared to have emerged simultaneously in January, 2020 and became present in more than $90 \%$ of all sequenced genomes by June, 2020. Additionally, some other mutations also emerged rapidly but then stabilized in frequency or faded out. For example, Q57H (NS3), R203K (N), G204R (N) are mutations that emerged rapidly and appeared to have stabilized at a frequency of $15 \%$ to $40 \%$. Others like I120F (NSP2), L37F (NSP6), S477N (S), and L84S (NS8) illustrate mutations that emerged rapidly and then faded-out just as quickly. We also demonstrate that most genes in SARS-CoV-2 have mutations with overall frequencies lower than 10\% (Fig.1). These mutations are also summarized into Table 1, which illustrates nucleotide substitution producing the amino acid change, the frequency, and their respective effects. Globally, there is an uneven effort to test for SARS-CoV-2 infections in the population and sequence the viral genomes in those infected. As a result, emerging mutations go unreported until they reach countries with more intensive sequencing capabilities. Therefore, mutations presented here vastly underrepresent the global landscape of mutation frequency dynamics.

\section{Geographic localization and timeline of the viral genes with mutations higher than $50 \%$ frequency.}

We next turned our attention to viral genes where at least one mutation reached a frequency higher than $50 \%$. Only three genes met this criterion: NSP12, S, and N. We then took their mutation graphs and added worldwide geographic data provided from GISAID. Geomaps are useful to determine if a mutation is a localized and regional event or is found worldwide. In the S protein, D614G is found worldwide with initially higher reported cases in the US, UK, and Australia, probably due to more intense large-scale testing and sequencing, while A222V is mostly reported in the UK, but has not yet been reported in South America, Central and East African regions (Fig. 2A). Like D614G, P323L in the RdRp is also found worldwide, with higher reported cases in the US, UK, and Australia (Fig. 2B). The N gene does not yet have successful 
medRxiv preprint doi: https://doi.org/10.1101/2021.03.06.21252994; this version posted May 15, 2021. The copyright holder for this preprint (which was not certified by peer review) is the author/funder, who has granted medRxiv a license to display the preprint in perpetuity. It is made available under a CC-BY 4.0 International license.

Castonguay et al., 2021

Genome Evolution of SARS-CoV-2

mutations that have attained reference sequence status, but R203K, G204R, A220V, D3L, and S235F all reached a frequency of 50\% or higher during the study period. A220V emerged in August of 2020 and reached a frequency higher than 50\% in October of 2020 (Fig. 2D). Mutations G204R, R203K and A220V in $\mathrm{N}$ gene are reported at high frequency in the UK, but were not been detected in South America, Central, East, and South African regions (Fig. 2C). We also observe the emergence of several mutations in $\mathrm{S}$ and $\mathrm{N}$ present in the B.1.1.7 variant, which now have a frequency higher than 65\% (Fig. 2C, 2D and Table 2). The analysis of these data illustrate the localization of the most prevalent mutations to date, which appear to be mostly present in Western high-income countries. This, however, is undoubtable attributable to overall more intense testing and sequencing.

Localization and molecular interactions of prevalent $\mathbf{S}$ protein mutations. Here we illustrate the molecular interactions and spatial localization of the mutations in the S protein. PyMOL was used to model structures of the S protein binding to ACE2 and we analyze the possible effects of specific mutations at given positions in the protein. Figure $\mathbf{3 A}$ presents an overview of the physical positions of $\mathrm{S}$ protein mutations. The A222V mutation has no reported effects on protein stability, neutralizing antibody escape, and affinity for hACE2 (Table 1). The substitution from A to $\mathrm{V}$ results in a low steric clash between neighboring residues (Fig. 3B). The S477N substitution in the RBD enables increased stability during hACE2-RBD interactions (Fig. 3C, Table 1). In the N-terminal domain (NTD), mutation L18F leads to a steric clash between neighboring residues (Fig. 3D). However, this does not appear to impact the stability of the protein given that no such effects have been reported so far (Table 1). In the closed conformation, D614 makes an ionic bond with K854 in the S2 subunit of another S protein monomer (Fig. 3F) (29). In the open conformation, D614 (or G614) doesn't make interactions or display steric clashes with neighboring residues (Fig. 3E).

The emergence of the B.1.1.7 variant in the UK. A new variant was discovered in late 2020 in the UK that displayed increased affinity to hACE2, virulence and Nabs escape capabilities (Fig. 4) (24,25,30,31). Here we further investigated the B.1.1.7 variant by looking at $\mathrm{S}$ protein mutations of this variant in complex with Nabs and hACE2. We mapped the localization of mutations with available Cryo-EM structures of the $\mathrm{S}$ protein and assessed the frequency of the variant by interrogating the GISAID database. There are nine mutations in the $\mathrm{S}$ protein out of the total 24 mutations in the B.1.1.7 SARS-CoV-2 genome (Fig. 5A \& 5E). Mutations in the S protein of the B.1.1.7 variant, except D614G, emerged in October of 2020 and reached a worldwide frequency of 70\% to $80 \%$ in April 2021 (Fig. 4, Fig. 5C, Table 2). N501Y, found in the RBD, can interact with K353 in hACE2 (Fig. 5B \& 5D, Fig. 8C). The N501Y mutation is associated with an increased affinity to hACE2, along with an increase in infectivity and virulence (Table 2). Figure 5G illustrates the whole genome of SARS-CoV-2 with all nucleotide substitutions of the B.1.1.7 variant. 
medRxiv preprint doi: https://doi.org/10.1101/2021.03.06.21252994; this version posted May 15, 2021. The copyright holder for this preprint (which was not certified by peer review) is the author/funder, who has granted medRxiv a license to display the preprint in perpetuity. It is made available under a CC-BY 4.0 International license.

Substitutions C913T, C5986T, C14676T, C15279T, C16176T in ORF1ab, and T26801C in M protein are all synonymous mutations. Also, the $\mathrm{C} 27972 \mathrm{~T}$ mutation has a frequency of $75 \%$ and produces a premature stop codon in NS8 that inactivates the protein (Q27stop) without obvious consequences (Fig. 5E, Table 2) (32). These results allow us to better understand the frequencies, localization, and interactions of mutations in the S protein of the B.1.1.7 variant. For viruses, both synonymous and non-synonymous mutations are of importance. Synonymous mutations that don't change the amino acid sequence of proteins can still exercise very important functions. They can play a key role in docking sites for RNA binding proteins, transcription factors and primers, or partake in important secondary structures of the viral RNA like functional loops and folds.

The emergence of the B.1.351 variant in South Africa. During the spread of the B.1.1.7 variant in the UK, another variant was emerging in South Africa, known as B.1.351 (21,22). The GISAID database was used to identify mutations and Cryo-EM structures of the $S$ protein to model the effects of point mutations (Fig. 6). Most of the mutations in the S protein of the B.1.351 variant are localized in the S1 subunit, with only A701V in the S2 subunit. Additionally, three mutations reside in the RBD, among which two of them are not found in the B.1.1.7 variant (K417N, E484K) (Fig. 6A, 6B). However, this variant contains D614G and N501Y, which are also seen in the B.1.1.7 variant (Fig. 5A). Furthermore, many of the mutations found in the B.1.351 variant have worldwide frequencies lower than 5\%. The exception is D614G, L18F and N501Y (Fig. 6C, Table 3). In comparison to B.1.1.7 and P.1 variants, the B.1.351 variant has not reached a frequency higher than 2\% as of April 2021 (Fig. 4). By using the mutagenesis tool of PyMOL, we modeled the S protein in complex with hACE2, and with C103 and C121 Nabs, which are human recombinant class I \& II neutralizing antibodies, respectively (33). Our in silico mutagenesis modelling predicts that B.1.352 mutations in the RBD favor a loss of interactions with C102 and C121 Nabs. Diminished interactions between RBD and C102 are predicted when the K417 is mutated to Asn producing Nabs escape capabilities (Fig. 6D, 8A). Diminished interactions with RBD are also predicted with $\mathrm{C} 121$ when the E484K mutation is present (Fig. 6E, 8B). As previously mentioned, N501Y is also found in B.1.351 and our modeling predicts that it will have similar effects as those observed with the B.1.1.7 variant (Fig. 6F). Figure 6G illustrates the position of the nucleotide substitutions of the B.1.351 variant.

The emergence of the P.1 variant in Brazil. Similar to the B.1.351 variant, the P.1 variant harbours the $\mathrm{N} 501 \mathrm{Y}$ and $\mathrm{E} 484 \mathrm{~K}$ mutations, but position 417 of the S protein displays a threonine (T) instead of a lysine (K) residue (23) (Fig. 7). Similar to the UK and South African variants, we present in Figure 7C mutations in the S protein that are characteristic of the P.1 variant and their frequencies from December 2019 to April $30^{\text {th }}$ 2021. The P.1 variant harbours amino acid substitutions L18F, T20N, P26S, D138Y, and R190S in the NTD of the S protein. H655Y and T1027I, V1176F are in the subdomain 2 (SD2) of S1 and in the S2 
medRxiv preprint doi: https://doi.org/10.1101/2021.03.06.21252994; this version posted May 15, 2021. The copyright holder for this preprint (which was not certified by peer review) is the author/funder, who has granted medRxiv a license to display the preprint in perpetuity. It is made available under a CC-BY 4.0 International license.

Castonguay et al., 2021

Genome Evolution of SARS-CoV-2

subunit, respectively (Fig. 7A, 7B, Table 4). The V1176F mutation is not shown because the structure is unresolved in this region. Overall, P.1-specific mutations have currently worldwide frequencies less than 5\% (Fig. 7C, Table 4). D614G, L18F and N501Y are not specific to P1. Similar to B.1.351, the P.1 variant has a low frequency representing less than 5\% of global variants as of April, 2021 (Fig. 4). Here, we also modeled P.1 mutations to investigate interaction alterations with known recombinant neutralizing antibodies (33). The K417T mutation reduces interactions with neighboring residues in the C102 Nab and therefore the model predicts, as with $\mathrm{K} 417 \mathrm{~N}$ in B.1.1.7, an increased ability to escape neutralization (Fig. 7D). Also, the P.1 variant has E484K and N501Y mutations in the RBD. Modelling predicts they will have the same effect reported for the B.1.1.7 and B.1.351 variants (Fig. 7E, 7F). In Figure 7G, we indicate the positions of synonymous, non-synonymous, and deletions in the SARS-CoV-2 P.1 genome.

\section{DISCUSSION}

The emergence of new genetic variants that are more transmissible, virulent and resistant to antibody neutralization have highlighted the importance of studying the function of mutations in the viral genome. The number of sequenced viral genomes uploaded to the GISAID database grew rapidly from 131,417 at the end of September, 2020 to 451,913 by January $30^{\text {th }}, 2021$ (28). GISAID is a formidable tool for tracking the emergence of mutations, identifying the geographic region where it emerged, and tracking its spread around the globe. Given the risk mutations and new variants pose for neutralizing antibody therapy and vaccines for SARS-CoV-2, it is crucial to continuously monitor the susceptibility of these variants to neutralization by humoral and cellular immune responses either induced through natural exposure to the reference strain or induced by vaccination $(24,25,33)$. Recent reports on the efficacy of the various vaccines have shown that these are variable and often diminished against variants (Tables 5 and 6). Most available vaccines generally remain near fully efficacious against the B.1.1.7 variant (31,34,35). However, the Oxford-AstraZeneca vaccine has displayed compromised efficacy against the B.1.351 variant with only $10 \%$ vaccine efficacy (36). Preliminary data with the Pfizer-BioNTech and Moderna mRNA vaccines also show a reduction in efficacy against B.1.351 $(35,37,38)$. Furthermore, antibodies induced by the PfizerBioNTech and Moderna vaccines appear to display a 6.7-fold, and 4.5-fold decrease in neutralization efficacy against the P.1 variant (Table 6) (39). The recently approved Johnson \& Johnson adenovirus-based vaccine only requires a single dose, in comparison to two for the mRNA vaccines and Oxford-AstraZeneca vaccine, and has an efficacy of 66\% against the original Wuhan reference strain, 52.0 to $64.0 \%$ against the B.1.351 variant and 66\% against the P.1 variant (43). The Novavax vaccine also shows reduced efficacy against the variants with $86 \%$ and 51\% against the B.1.1.7 and P.1 variants, respectively. Nevertheless, humoral responses are only one component of the adaptive immune response. $\mathrm{T}$ cell responses have not 
medRxiv preprint doi: https://doi.org/10.1101/2021.03.06.21252994; this version posted May 15, 2021. The copyright holder for this preprint (which was not certified by peer review) is the author/funder, who has granted medRxiv a license to display the preprint in perpetuity. Castonguay et al., 2021 Genome Evolution of SARS-CoV-2

been studied in detail against these variants at this time and still provide robust contribution to overall protection against severe COVID-19 disease.

Studying the effect of individual mutations in a viral protein may not always reflect their true impact on virus features if they appear in combination with other mutations. Epistasis is the combinatory effect of two or more mutations in a genome (50). Epistasis has previously been intensely studied in the surface protein hemagglutinin (HA) of influenza viruses and positive epistasis was identified in several regions of the HA receptor-binding domain (51). In relation to the $\mathrm{S}$ protein of SARS-CoV-2, epistatic mutations could, for instance, allow the $\mathrm{S}$ protein to adopt a specific conformation when all the mutations are present, thereby producing a unique folding of the protein and enabling new features. A recent study demonstrated the impact of antigenicity and infectivity of D614G SARS-CoV-2 variants with a combination of different mutations occurring in the S protein (19). The study shows that D614G alone only mildly increases infectivity, but in combination with different other mutations in the S protein, together these can either more intensely increase or decrease viral infectivity. Similar findings have been reported regarding sensitivity to Nabs. D614G alone has undetectable effects on Nabs escape. However, the combination of D614G with other mutations in $\mathrm{S}$ can enable Nabs escape (19). This data suggests that the continuous emergence of epistatic mutations in SARS-CoV-2 will likely be involved in further altering the properties of the virus, including transmissibility, pathogenicity, stability and Nab resistance.

Our analyses have highlighted that several new fast-spreading mutations had frequency trajectories that eventually plunged or stabilized at low frequencies. Only the D614G in the S protein and the P323L in the RdRp have maintained their presence in the consensus sequence (Fig. 1 and 2). Analyses of the GISAID database also reveal which countries upload the most sequences to the database and are therefore carrying out the most testing and sequencing. The global frequency of mutations and variants in the database is therefore biased to represent the genetic landscape of the virus in the countries doing the most testing, sequencing, and data sharing. Emergence of new variants may therefore go undetected until they leave their point of origin and enter countries with high testing and sequencing rates. This delayed notification constitutes a major obstacle in identifying and preventing the spread of nefarious variants that are potentially resistant to current vaccines and neutralizing antibody therapy. Another caveat in analyzing sequences in the GISAID database is that consensus sequences are uploaded, but subsequences and quasispecies are generally not included. Therefore, it is possible that mutations in sub-variants may be missed that could contribute to virus replication, pathogenicity, and spread (52). A global approach to analyzing both transmitted variants and non-transmitted sub-variants and quasispecies could provide a better understanding of the effects of SARS-CoV-2 mutations. 
medRxiv preprint doi: https://doi.org/10.1101/2021.03.06.21252994; this version posted May 15, 2021. The copyright holder for this preprint (which was not certified by peer review) is the author/funder, who has granted medRxiv a license to display the preprint in perpetuity.

Castonguay et al., 2021

Genome Evolution of SARS-CoV-2

In conclusion, our metadata analysis of emerging mutations has highlighted the natural fluctuations in mutation prevalence. We also illustrate how mutations sometimes need to co-emerge in order to create a favorable outcome for virus propagation. Tracking mutations and the evolution of the SARS-CoV-2 genome is critical for the development and deployment of effective treatments and vaccines. Thus, it is the responsibility of all countries and governing jurisdictions to increase testing and sequencing, and uploading SARS-CoV-2 genomes to open access databases in real-time. This will result in more accurate information to inform policy and decision makers about interventions required to blunt the global transmission of the virus and ensure that vaccines remain effective against all circulating variants. 
medRxiv preprint doi: https://doi.org/10.1101/2021.03.06.21252994; this version posted May 15, 2021. The copyright holder for this preprint (which was not certified by peer review) is the author/funder, who has granted medRxiv a license to display the preprint in perpetuity.

Castonguay et al., 2021

Genome Evolution of SARS-CoV-2

\section{ACKNOWLEDGEMENTS}

The authors wish to thank Dr. Sean Li at Health Canada for helpful comments on our manuscript. M.-A.L. holds a Canada Research Chair in Molecular Virology and Intrinsic Immunity. This study was supported by a COVID-19 Rapid Response grant to M-A Langlois by the Canadian Institute of Health Research (CIHR) and by a grant supplement by the Canadian Immunity Task Force (CITF).

\section{CONFLICTS OF INTERESTS}

The authors declare no competing interests. 
medRxiv preprint doi: https://doi.org/10.1101/2021.03.06.21252994; this version posted May 15, 2021. The copyright holder for this preprint

(which was not certified by peer review) is the author/funder, who has granted medRxiv a license to display the preprint in perpetuity.

It is made available under a CC-BY 4.0 International license .

Castonguay et al., 2021

Genome Evolution of SARS-CoV-2

\section{REFERENCES}

1. Zhu N, Zhang D, Wang W, Li X, Yang B, Song J, Zhao X, Huang B, Shi W, Lu R, Niu P, Zhan F, Ma X, Wang D, Xu W, Wu G, Gao GF, Tan W. 2020. A Novel Coronavirus from Patients with Pneumonia in China, 2019. N Engl J Med 382:727-733.

2. Dong E, Du H, Gardner L. 2020. An interactive web-based dashboard to track COVID-19 in real time. The Lancet Infectious Diseases 20:533-534.

3. Wu F, Zhao S, Yu B, Chen Y-M, Wang W, Song Z-G, Hu Y, Tao Z-W, Tian J-H, Pei Y-Y, Yuan ML, Zhang Y-L, Dai F-H, Liu Y, Wang Q-M, Zheng J-J, Xu L, Holmes EC, Zhang Y-Z. 2020. A new coronavirus associated with human respiratory disease in China. Nature 579:265-269.

4. Kim D, Lee J-Y, Yang J-S, Kim JW, Kim VN, Chang H. 2020. The Architecture of SARS-CoV-2 Transcriptome. Cell 181:914-921.e10.

5. Duffy S. 2018. Why are RNA virus mutation rates so damn high? PLOS Biology 16:e3000003.

6. Drake JW. 1993. Rates of spontaneous mutation among RNA viruses. Proc Natl Acad Sci USA 90:4171.

7. Peck KM, Lauring AS. 2018. Complexities of Viral Mutation Rates. J Virol 92:e01031-17.

8. Eckerle LD, Becker MM, Halpin RA, Li K, Venter E, Lu X, Scherbakova S, Graham RL, Baric RS, Stockwell TB, Spiro DJ, Denison MR. 2010. Infidelity of SARS-CoV Nsp14-Exonuclease Mutant Virus Replication Is Revealed by Complete Genome Sequencing. PLOS Pathogens 6:e1000896.

9. Minskaia E, Hertzig T, Gorbalenya AE, Campanacci V, Cambillau C, Canard B, Ziebuhr J. 2006. Discovery of an RNA virus $3^{\prime} \rightarrow 5^{\prime}$ exoribonuclease that is critically involved in coronavirus RNA synthesis. Proc Natl Acad Sci U S A 103:5108.

10. Ma Y, Wu L, Shaw N, Gao Y, Wang J, Sun Y, Lou Z, Yan L, Zhang R, Rao Z. 2015. Structural basis and functional analysis of the SARS coronavirus nsp14-nsp10 complex. Proc Natl Acad Sci USA 112:9436.

11. Rausch JW, Capoferri AA, Katusiime MG, Patro SC, Kearney MF. 2020. Low genetic diversity may be an Achilles heel of SARS-CoV-2. Proc Natl Acad Sci USA 117:24614.

12. Chu H, Chan JF-W, Yuen TT-T, Shuai H, Yuan S, Wang Y, Hu B, Yip CC-Y, Tsang JO-L, Huang X, Chai Y, Yang D, Hou Y, Chik KK-H, Zhang X, Fung AY-F, Tsoi H-W, Cai J-P, Chan W-M, Ip JD, Chu AW-H, Zhou J, Lung DC, Kok K-H, To KK-W, Tsang OT-Y, Chan K-H, Yuen K-Y. 2020. Comparative tropism, replication kinetics, and cell damage profiling of SARS-CoV-2 and SARS-CoV with implications for clinical manifestations, transmissibility, and laboratory studies of COVID-19: an observational study. The Lancet Microbe 1:e14-e23.

13. Shi J, Wen Z, Zhong G, Yang H, Wang C, Huang B, Liu R, He X, Shuai L, Sun Z, Zhao Y, Liu P, Liang L, Cui P, Wang J, Zhang X, Guan Y, Tan W, Wu G, Chen H, Bu Z. 2020. Susceptibility of 
medRxiv preprint doi: https://doi.org/10.1101/2021.03.06.21252994; this version posted May 15, 2021. The copyright holder for this preprint

(which was not certified by peer review) is the author/funder, who has granted medRxiv a license to display the preprint in perpetuity. It is made available under a CC-BY 4.0 International license.

Castonguay et al., 2021

Genome Evolution of SARS-CoV-2

ferrets, cats, dogs, and other domesticated animals to SARS-coronavirus 2. Science 368:1016.

14. Li X, Giorgi EE, Marichannegowda MH, Foley B, Xiao C, Kong X-P, Chen Y, Gnanakaran S, Korber B, Gao F. 2020. Emergence of SARS-CoV-2 through recombination and strong purifying selection. Sci Adv 6:eabb9153.

15. Walls AC, Park Y-J, Tortorici MA, Wall A, McGuire AT, Veesler D. 2020. Structure, Function, and Antigenicity of the SARS-CoV-2 Spike Glycoprotein. Cell 181:281-292.e6.

16. Plante JA, Liu Y, Liu J, Xia H, Johnson BA, Lokugamage KG, Zhang X, Muruato AE, Zou J, FontesGarfias CR, Mirchandani D, Scharton D, Bilello JP, Ku Z, An Z, Kalveram B, Freiberg AN, Menachery VD, Xie X, Plante KS, Weaver SC, Shi P-Y. 2020. Spike mutation D614G alters SARS-CoV-2 fitness. Nature https://doi.org/10.1038/s41586-020-2895-3.

17. Zhang L, Jackson CB, Mou H, Ojha A, Peng H, Quinlan BD, Rangarajan ES, Pan A, Vanderheiden A, Suthar MS, Li W, Izard T, Rader C, Farzan M, Choe H. 2020. SARS-CoV-2 spike-protein D614G mutation increases virion spike density and infectivity. Nature Communications 11:6013.

18. Korber B, Fischer WM, Gnanakaran S, Yoon H, Theiler J, Abfalterer W, Hengartner N, Giorgi EE, Bhattacharya T, Foley B, Hastie KM, Parker MD, Partridge DG, Evans CM, Freeman TM, de Silva TI, Angyal A, Brown RL, Carrilero L, Green LR, Groves DC, Johnson KJ, Keeley AJ, Lindsey BB, Parsons PJ, Raza M, Rowland-Jones S, Smith N, Tucker RM, Wang D, Wyles MD, McDanal C, Perez LG, Tang H, Moon-Walker A, Whelan SP, LaBranche CC, Saphire EO, Montefiori DC. 2020. Tracking Changes in SARS-CoV-2 Spike: Evidence that D614G Increases Infectivity of the COVID-19 Virus. Cell 182:812-827.e19.

19. Li Q, Wu J, Nie J, Zhang L, Hao H, Liu S, Zhao C, Zhang Q, Liu H, Nie L, Qin H, Wang M, Lu Q, Li X, Sun Q, Liu J, Zhang L, Li X, Huang W, Wang Y. 2020. The Impact of Mutations in SARS-CoV-2 Spike on Viral Infectivity and Antigenicity. Cell, 2020/07/17 ed. 182:1284-1294.e9.

20. Rambaut A, Loman N, Pybus O, Barclay W, Barrett J, Carabelli A, Connor T, Peacock T, Robertson D, Volz E, on behalf of CoG-UK. 2020. Preliminary genomic characterisation of an emergent SARSCoV-2 lineage in the UK defined by a novel set of spike mutations. https://virological.org/t/preliminary-genomic-characterisation-of-an-emergent-sars-cov-2-lineage-inthe-uk-defined-by-a-novel-set-of-spike-mutations/563

21. O'Toole, A, Hill V, et al. (2021) Tracking the international spread of SARS-CoV-2 lineage B.1.1.7 and B.1.351/501Y-V2. https://virological.org/t/tracking-the-international-spread-of-sars-cov-2-lineages-b1-1-7-and-b-1-351-501y-v2/592

22. Tegally H, Wilkinson E, Giovanetti M, Iranzadeh A, Fonseca V, Giandhari J, Doolabh D, Pillay S, San EJ, Msomi N, Mlisana K, von Gottberg A, Walaza S, Allam M, Ismail A, Mohale T, Glass AJ, Engelbrecht S, Van Zyl G, Preiser W, Petruccione F, Sigal A, Hardie D, Marais G, Hsiao N, Korsman S, Davies M-A, Tyers L, Mudau I, York D, Maslo C, Goedhals D, Abrahams S, Laguda-Akingba O, Alisoltani-Dehkordi A, Godzik A, Wibmer CK, Sewell BT, Lourenço J, Alcantara LCJ, Kosakovsky Pond SL, Weaver S, Martin D, Lessells RJ, Bhiman JN, Williamson C, de Oliveira T. 2021. Detection 
medRxiv preprint doi: https://doi.org/10.1101/2021.03.06.21252994; this version posted May 15, 2021. The copyright holder for this preprint

(which was not certified by peer review) is the author/funder, who has granted medRxiv a license to display the preprint in perpetuity.

It is made available under a CC-BY 4.0 International license .

Castonguay et al., 2021

Genome Evolution of SARS-CoV-2

of a SARS-CoV-2 variant of concern in South Africa. Nature 592:438-443.

23. Faria, Nuno R.; et al. (12 January 2021). Genomic characterisation of an emergent SARS-CoV-2 lineage in Manaus: preliminary findings. Virological. Retrieved 23 January 2021. https://virological.org/t/genomic-characterisation-of-an-emergent-sars-cov-2-lineage-in-manauspreliminary-findings/586

24. Wang P, Liu L, Iketani S, Luo Y, Guo Y, Wang M, Yu J, Zhang B, Kwong PD, Graham BS, Mascola JR, Chang JY, Yin MT, Sobieszczyk M, Kyratsous CA, Shapiro L, Sheng Z, Nair MS, Huang Y, Ho DD. 2021. Increased Resistance of SARS-CoV-2 Variants B.1.351 and B.1.1.7 to Antibody Neutralization. bioRxiv 2021.01.25.428137.

25. Greaney AJ, Starr TN, Gilchuk P, Zost SJ, Binshtein E, Loes AN, Hilton SK, Huddleston J, Eguia R, Crawford KHD, Dingens AS, Nargi RS, Sutton RE, Suryadevara N, Rothlauf PW, Liu Z, Whelan SPJ, Carnahan RH, Crowe JE Jr, Bloom JD. 2021. Complete Mapping of Mutations to the SARS-CoV-2 Spike Receptor-Binding Domain that Escape Antibody Recognition. Cell Host \& Microbe 29:44-57.e9.

26. Yi C, Sun X, Ye J, Ding L, Liu M, Yang Z, Lu X, Zhang Y, Ma L, Gu W, Qu A, Xu J, Shi Z, Ling Z, Sun B. 2020. Key residues of the receptor binding motif in the spike protein of SARS-CoV-2 that interact with ACE2 and neutralizing antibodies. Cellular \& Molecular Immunology 17:621-630.

27. Gu H, Chen Q, Yang G, He L, Fan H, Deng Y-Q, Wang Y, Teng Y, Zhao Z, Cui Y, Li Y, Li X-F, Li J, Zhang N-N, Yang X, Chen S, Guo Y, Zhao G, Wang X, Luo D-Y, Wang H, Yang X, Li Y, Han G, He Y, Zhou X, Geng S, Sheng X, Jiang S, Sun S, Qin C-F, Zhou Y. 2020. Adaptation of SARS-CoV2 in BALB/c mice for testing vaccine efficacy. Science 369:1603.

28. Shu Y, McCauley J. 2017. GISAID: Global initiative on sharing all influenza data - from vision to reality. Euro Surveill 22:30494.

29. Benton DJ, Wrobel AG, Xu P, Roustan C, Martin SR, Rosenthal PB, Skehel JJ, Gamblin SJ. 2020. Receptor binding and priming of the spike protein of SARS-CoV-2 for membrane fusion. Nature 588:327-330.

30. Starr TN, Greaney AJ, Hilton SK, Ellis D, Crawford KHD, Dingens AS, Navarro MJ, Bowen JE, Tortorici MA, Walls AC, King NP, Veesler D, Bloom JD. 2020. Deep Mutational Scanning of SARSCoV-2 Receptor Binding Domain Reveals Constraints on Folding and ACE2 Binding. Cell 182:12951310.e20.

31. Haas EJ, Angulo FJ, McLaughlin JM, Anis E, Singer SR, Khan F, Brooks N, Smaja M, Mircus G, Pan K, Southern J, Swerdlow DL, Jodar L, Levy Y, Alroy-Preis S. Impact and effectiveness of mRNA BNT162b2 vaccine against SARS-CoV-2 infections and COVID-19 cases, hospitalisations, and deaths following a nationwide vaccination campaign in Israel: an observational study using national surveillance data. The Lancet https://doi.org/10.1016/S0140-6736(21)00947-8.

32. Pereira F. 2020. Evolutionary dynamics of the SARS-CoV-2 ORF8 accessory gene. Infect Genet Evol, 2020/09/02 ed. 85:104525-104525. 
medRxiv preprint doi: https://doi.org/10.1101/2021.03.06.21252994; this version posted May 15, 2021. The copyright holder for this preprint

(which was not certified by peer review) is the author/funder, who has granted medRxiv a license to display the preprint in perpetuity. It is made available under a CC-BY 4.0 International license.

Castonguay et al., 2021

Genome Evolution of SARS-CoV-2

33. Barnes CO, Jette CA, Abernathy ME, Dam K-MA, Esswein SR, Gristick HB, Malyutin AG, Sharaf NG, Huey-Tubman KE, Lee YE, Robbiani DF, Nussenzweig MC, West AP, Bjorkman PJ. 2020. SARS-CoV-2 neutralizing antibody structures inform therapeutic strategies. Nature 588:682-687.

34. Emary KRW, Golubchik T, Aley PK, Ariani CV, Angus B, Bibi S, Blane B, Bonsall D, Cicconi P, Charlton S, Clutterbuck EA, Collins AM, Cox T, Darton TC, Dold C, Douglas AD, Duncan CJA, Ewer KJ, Flaxman AL, Faust SN, Ferreira DM, Feng S, Finn A, Folegatti PM, Fuskova M, Galiza E, Goodman AL, Green CM, Green CA, Greenland M, Hallis B, Heath PT, Hay J, Hill HC, Jenkin D, Kerridge S, Lazarus R, Libri V, Lillie PJ, Ludden C, Marchevsky NG, Minassian AM, McGregor AC, Mujadidi YF, Phillips DJ, Plested E, Pollock KM, Robinson H, Smith A, Song R, Snape MD, Sutherland RK, Thomson EC, Toshner M, Turner DPJ, Vekemans J, Villafana TL, Williams CJ, Hill AVS, Lambe T, Gilbert SC, Voysey M, Ramasamy MN, Pollard AJ. 2021. Efficacy of ChAdOx1 nCoV-19 (AZD1222) vaccine against SARS-CoV-2 variant of concern 202012/01 (B.1.1.7): an exploratory analysis of a randomised controlled trial. The Lancet 397:1351-1362.

35. Wu K, Werner AP, Koch M, Choi A, Narayanan E, Stewart-Jones GBE, Colpitts T, Bennett H, Boyoglu-Barnum S, Shi W, Moliva JI, Sullivan NJ, Graham BS, Carfi A, Corbett KS, Seder RA, Edwards DK. 2021. Serum Neutralizing Activity Elicited by mRNA-1273 Vaccine - Preliminary Report. N Engl J Med https://doi.org/10.1056/NEJMc2102179

36. Madhi SA, Baillie V, Cutland CL, Voysey M, Koen AL, Fairlie L, Padayachee SD, Dheda K, Barnabas SL, Bhorat QE, Briner C, Kwatra G, Ahmed K, Aley P, Bhikha S, Bhiman JN, Bhorat AE, du Plessis J, Esmail A, Groenewald M, Horne E, Hwa S-H, Jose A, Lambe T, Laubscher M, Malahleha M, Masenya M, Masilela M, McKenzie S, Molapo K, Moultrie A, Oelofse S, Patel F, Pillay S, Rhead S, Rodel H, Rossouw L, Taoushanis C, Tegally H, Thombrayil A, van Eck S, Wibmer CK, Durham NM, Kelly EJ, Villafana TL, Gilbert S, Pollard AJ, de Oliveira T, Moore PL, Sigal A, Izu A. 2021. Efficacy of the ChAdOx1 nCoV-19 Covid-19 Vaccine against the B.1.351 Variant. $N$ Engl J Med https://doi.org/10.1056/NEJMoa2102214.

37. Abu-Raddad LJ, Chemaitelly H, Butt AA. 2021. Effectiveness of the BNT162b2 Covid-19 Vaccine against the B.1.1.7 and B.1.351 Variants. N Engl J Med https://doi.org/10.1056/NEJMc2104974.

38. Liu Y, Liu J, Xia H, Zhang X, Fontes-Garfias CR, Swanson KA, Cai H, Sarkar R, Chen W, Cutler M, Cooper D, Weaver SC, Muik A, Sahin U, Jansen KU, Xie X, Dormitzer PR, Shi P-Y. 2021. Neutralizing Activity of BNT162b2-Elicited Serum - Preliminary Report. $N$ Engl J Med https://doi.org/10.1056/NEJMc2102017.

39. Garcia-Beltran WF, Lam EC, St. Denis K, Nitido AD, Garcia ZH, Hauser BM, Feldman J, Pavlovic MN, Gregory DJ, Poznansky MC, Sigal A, Schmidt AG, Iafrate AJ, Naranbhai V, Balazs AB. 2021. Multiple SARS-CoV-2 variants escape neutralization by vaccine-induced humoral immunity. Cell https://doi.org/10.1016/j.cell.2021.03.013.

40. Polack FP, Thomas SJ, Kitchin N, Absalon J, Gurtman A, Lockhart S, Perez JL, Pérez Marc G, Moreira ED, Zerbini C, Bailey R, Swanson KA, Roychoudhury S, Koury K, Li P, Kalina WV, Cooper D, Frenck RW, Hammitt LL, Türeci Ö, Nell H, Schaefer A, Ünal S, Tresnan DB, Mather S, Dormitzer PR, Şahin 
medRxiv preprint doi: https://doi.org/10.1101/2021.03.06.21252994; this version posted May 15, 2021. The copyright holder for this preprint

(which was not certified by peer review) is the author/funder, who has granted medRxiv a license to display the preprint in perpetuity. It is made available under a CC-BY 4.0 International license .

Castonguay et al., $2021 \quad$ Genome Evolution of SARS-CoV-2

U, Jansen KU, Gruber WC. 2020. Safety and Efficacy of the BNT162b2 mRNA Covid-19 Vaccine. $N$ Engl J Med 383:2603-2615.

41. Baden LR, El Sahly HM, Essink B, Kotloff K, Frey S, Novak R, Diemert D, Spector SA, Rouphael N, Creech CB, McGettigan J, Khetan S, Segall N, Solis J, Brosz A, Fierro C, Schwartz H, Neuzil K, Corey L, Gilbert P, Janes H, Follmann D, Marovich M, Mascola J, Polakowski L, Ledgerwood J, Graham BS, Bennett H, Pajon R, Knightly C, Leav B, Deng W, Zhou H, Han S, Ivarsson M, Miller J, Zaks T. 2020. Efficacy and Safety of the mRNA-1273 SARS-CoV-2 Vaccine. N Engl J Med 384:403-416.

42. Voysey M, Clemens SAC, Madhi SA, et al. 2021. Safety and efficacy of the ChAdOx1 nCoV-19 vaccine (AZD1222) against SARS-CoV-2: an interim analysis of four randomised controlled trials in Brazil, South Africa, and the UK. The Lancet 397:99-111.

43. Sadoff J, Gray G, Vandebosch A, Cárdenas V, Shukarev G, Grinsztejn B, Goepfert PA, Truyers C, Fennema H, Spiessens B, Offergeld K, Scheper G, Taylor KL, Robb ML, Treanor J, Barouch DH, Stoddard J, Ryser MF, Marovich MA, Neuzil KM, Corey L, Cauwenberghs N, Tanner T, Hardt K, Ruiz-Guiñazú J, Le Gars M, Schuitemaker H, Van Hoof J, Struyf F, Douoguih M. 2021. Safety and Efficacy of Single-Dose Ad26.COV2.S Vaccine against Covid-19. $N$ Engl $J$ Med https://doi.org/10.1056/NEJMoa2101544.

44. Shinde V, Bhikha S, Hoosain Z, Archary M, Bhorat Q, Fairlie L, Lalloo U, Masilela MSL, Moodley D, Hanley S, Fouche L, Louw C, Tameris M, Singh N, Goga A, Dheda K, Grobbelaar C, Kruger G, Carrim-Ganey N, Baillie V, de Oliveira T, Lombard Koen A, Lombaard JJ, Mngqibisa R, Bhorat AE, Benadé G, Lalloo N, Pitsi A, Vollgraaff P-L, Luabeya A, Esmail A, Petrick FG, Oommen-Jose A, Foulkes S, Ahmed K, Thombrayil A, Fries L, Cloney-Clark S, Zhu M, Bennett C, Albert G, Faust E, Plested JS, Robertson A, Neal S, Cho I, Glenn GM, Dubovsky F, Madhi SA. 2021. Efficacy of NVXCoV2373 Covid-19 Vaccine against the B.1.351 Variant. $N$ Engl $J$ Med https://doi.org/10.1056/NEJMoa2103055.

45. Supasa P, Zhou D, Dejnirattisai W, Liu C, Mentzer AJ, Ginn HM, Zhao Y, Duyvesteyn HME, Nutalai R, Tuekprakhon A, Wang B, Paesen GC, Slon-Campos J, López-Camacho C, Hallis B, Coombes N, Bewley KR, Charlton S, Walter TS, Barnes E, Dunachie SJ, Skelly D, Lumley SF, Baker N, Shaik I, Humphries HE, Godwin K, Gent N, Sienkiewicz A, Dold C, Levin R, Dong T, Pollard AJ, Knight JC, Klenerman P, Crook D, Lambe T, Clutterbuck E, Bibi S, Flaxman A, Bittaye M, Belij-Rammerstorfer S, Gilbert S, Hall DR, Williams MA, Paterson NG, James W, Carroll MW, Fry EE, Mongkolsapaya J, Ren J, Stuart DI, Screaton GR. 2021. Reduced neutralization of SARS-CoV-2 B.1.1.7 variant by convalescent and vaccine sera. Cell 184:2201-2211.e7.

46. Zhou D, Dejnirattisai W, Supasa P, Liu C, Mentzer AJ, Ginn HM, Zhao Y, Duyvesteyn HME, Tuekprakhon A, Nutalai R, Wang B, Paesen GC, Lopez-Camacho C, Slon-Campos J, Hallis B, Coombes N, Bewley K, Charlton S, Walter TS, Skelly D, Lumley SF, Dold C, Levin R, Dong T, Pollard AJ, Knight JC, Crook D, Lambe T, Clutterbuck E, Bibi S, Flaxman A, Bittaye M, Belij-Rammerstorfer S, Gilbert S, James W, Carroll MW, Klenerman P, Barnes E, Dunachie SJ, Fry EE, Mongkolsapaya J, Ren J, Stuart DI, Screaton GR. 2021. Evidence of escape of SARS-CoV-2 variant B.1.351 from natural and vaccine-induced sera. Cell 184:2348-2361.e6. 
medRxiv preprint doi: https://doi.org/10.1101/2021.03.06.21252994; this version posted May 15, 2021. The copyright holder for this preprint

(which was not certified by peer review) is the author/funder, who has granted medRxiv a license to display the preprint in perpetuity. It is made available under a CC-BY 4.0 International license .

Castonguay et al., 2021

Genome Evolution of SARS-CoV-2

47. Dejnirattisai W, Zhou D, Supasa P, Liu C, Mentzer AJ, Ginn HM, Zhao Y, Duyvesteyn HME, Tuekprakhon A, Nutalai R, Wang B, Paesen GC, López-Camacho C, Slon-Campos J, Walter TS, Skelly D, Clemens SAC, Naveca FG, Nascimento V, Nascimento F, da Costa CF, Resende PC, Pauvolid-Correa A, Siqueira MM, Dold C, Levin R, Dong T, Pollard AJ, Knight JC, Crook D, Lambe T, Clutterbuck E, Bibi S, Flaxman A, Bittaye M, Belij-Rammerstorfer S, Gilbert S, Carroll MW, Klenerman P, Barnes E, Dunachie SJ, Paterson NG, Williams MA, Hall DR, Hulswit RJG, Bowden TA, Fry EE, Mongkolsapaya J, Ren J, Stuart DI, Screaton GR. 2021. Antibody evasion by the Brazilian P.1 strain of SARS-CoV-2. bioRxiv 2021.03.12.435194.

48. Shen X, Tang H, Pajon R, Smith G, Glenn GM, Shi W, Korber B, Montefiori DC. 2021. Neutralization of SARS-CoV-2 Variants B.1.429 and B.1.351. N Engl J Med https://doi.org/10.1056/NEJMc2103740.

49. Shen X, Tang H, McDanal C, Wagh K, Fischer W, Theiler J, Yoon H, Li D, Haynes BF, Sanders KO, Gnanakaran S, Hengartner N, Pajon R, Smith G, Glenn GM, Korber B, Montefiori DC. 2021. SARSCoV-2 variant B.1.1.7 is susceptible to neutralizing antibodies elicited by ancestral spike vaccines. Cell Host \& Microbe 29:529-539.e3.

50. Phillips PC. 2008. Epistasis - the essential role of gene interactions in the structure and evolution of genetic systems. Nature Reviews Genetics 9:855-867.

51. Wu NC, Xie J, Zheng T, Nycholat CM, Grande G, Paulson JC, Lerner RA, Wilson IA. 2017. Diversity of Functionally Permissive Sequences in the Receptor-Binding Site of Influenza Hemagglutinin. Cell Host \& Microbe 21:742-753.e8.

52. Rocheleau L, Laroche G, Fu K, Stewart CM, Mohamud AO, Côté M, Giguère PM, Langlois M-A, Pelchat M. 2021. Identification of a High-frequency Intra-host SARS-CoV-2 spike Variant with Enhanced Cytopathic and Fusogenic Effect. bioRxiv 2020.12.03.409714.

53. COVID-19 GENOMIC UK CONSORTIUM. 2021. COG-UK report on SARS-CoV-2 Spike mutations of interest in the UK. https://www.cogconsortium.uk/wp-content/uploads/2021/01/Report-2_COGUK_SARS-CoV-2-Mutations.pdf

54. Zahradník J, Marciano S, Shemesh M, Zoler E, Chiaravalli J, Meyer B, Rudich Y, Dym O, Elad N, Schreiber G. 2021. SARS-CoV-2 RBD in vitro evolution follows contagious mutation spread, yet generates an able infection inhibitor. bioRxiv 2021.01.06.425392.

55. Kannan SR, Spratt AN, Quinn TP, Heng X, Lorson CL, Sönnerborg A, Byrareddy SN, Singh K. 2020. Infectivity of SARS-CoV-2: there Is Something More than D614G? J Neuroimmune Pharmacol, 2020/09/15 ed. 15:574-577.

56. Ugurel OM, Mutlu O, Sariyer E, Kocer S, Ugurel E, Inci TG, Ata O, Turgut-Balik D. 2020. Evaluation of the potency of FDA-approved drugs on wild type and mutant SARS-CoV-2 helicase (Nsp13). Int J Biol Macromol, 2020/09/24 ed. 163:1687-1696.

57. Wu S, Tian C, Liu P, Guo D, Zheng W, Huang X, Zhang Y, Liu L. 2020. Effects of SARS-CoV-2 mutations on protein structures and intraviral protein-protein interactions. Journal of Medical 
medRxiv preprint doi: https://doi.org/10.1101/2021.03.06.21252994; this version posted May 15, 2021. The copyright holder for this preprint (which was not certified by peer review) is the author/funder, who has granted medRxiv a license to display the preprint in perpetuity.

Castonguay et al., 2021

Genome Evolution of SARS-CoV-2

Virology. 2021;93:2132-2140.

58. Weisblum Y, Schmidt F, Zhang F, DaSilva J, Poston D, Lorenzi JC, Muecksch F, Rutkowska M, Hoffmann H-H, Michailidis E, Gaebler C, Agudelo M, Cho A, Wang Z, Gazumyan A, Cipolla M, Luchsinger L, Hillyer CD, Caskey M, Robbiani DF, Rice CM, Nussenzweig MC, Hatziioannou T, Bieniasz PD. 2020. Escape from neutralizing antibodies by SARS-CoV-2 spike protein variants. eLife 9:e61312. 
medRxiv preprint doi: https://doi.org/10.1101/2021.03.06.21252994; this version posted May 15, 2021. The copyright holder for this preprint (which was not certified by peer review) is the author/funder, who has granted medRxiv a license to display the preprint in perpetuity.

It is made available under a CC-BY 4.0 International license

Castonguay et al., $2021 \quad$ Genome Evolution of SARS-CoV-2

\section{TABLES}

Table 1: Non-synonymous mutations in SARS-CoV-2 genes with a worldwide frequency $\geq 0.01 \%$.

\begin{tabular}{|c|c|c|c|c|c|}
\hline $\begin{array}{l}\text { Protein } \\
\text { (Gene) }\end{array}$ & $\begin{array}{c}\text { Genome } \\
\text { Nucleotide } \\
\text { Mutation }\end{array}$ & Codon & $\begin{array}{c}\text { AA } \\
\text { Mutation }\end{array}$ & $\begin{array}{l}\text { Frequency } \\
(\%)^{*}\end{array}$ & Effect \\
\hline \multirow[t]{16}{*}{$S$} & A23403G & GAT to GGT & D614G & 99.70 & $\begin{array}{l}\text { Moderate increase in } \\
\text { Transmissibility }{ }^{53}\end{array}$ \\
\hline & $\mathrm{C} 22227 \mathrm{~T}$ & GCT to GTT & A222V & 42.79 & No effect ${ }^{53}$ \\
\hline & $\mathrm{C} 21615 \mathrm{~T}$ & CTT to TTT & $\mathrm{L} 18 \mathrm{~F}$ & 19.86 & N/A \\
\hline & G22992A & $\mathrm{A} \mathbf{G C}$ to $\mathrm{AAC}$ & S477N & 5.36 & $\begin{array}{c}\text { Spike-hACE2 complex stability } \\
\text { and Nab interference } e^{54}\end{array}$ \\
\hline & C22879A & $\mathrm{AAC}$ to $\mathrm{AAA}$ & $\mathrm{N} 439 \mathrm{~K}$ & 4.09 & Antibody escape ability ${ }^{19,53}$ \\
\hline & $\mathrm{C} 21575 \mathrm{~T}$ & CTT to TTT & L5F & 1.44 & N/A \\
\hline & $\mathrm{C} 21855 \mathrm{~T}$ & TCT to TTT & S98F & 2.74 & N/A \\
\hline & G22346T & GCT to TCT & A262S & 1.64 & N/A \\
\hline & A23063T & AAT to TAT & N501Y & 80.16 & Increase affinity for hACE $2^{53}$ \\
\hline & $\mathrm{C} 23709 \mathrm{~T}$ & ACA to ATA & $\mathrm{T} 716 \mathrm{I}$ & 75.37 & N/A \\
\hline & C23271A & GCT to GAT & A570D & 76.30 & N/A \\
\hline & G24914C & GCA to $\mathbf{C A C}$ & D1118H & 74.82 & N/A \\
\hline & C23709A & CCT to CAT & $\mathrm{P} 681 \mathrm{H}$ & 79.18 & N/A \\
\hline & $\mathrm{T} 24506 \mathrm{G}$ & TCA to GCA & S982A & 74.61 & N/A \\
\hline & 21765-21770del & N/A & $\Delta \mathrm{H} 69 / \Delta \mathrm{V} 70$ & 75.13 & Antibody escape $\mathrm{e}^{53}$ \\
\hline & 21991-21993del & N/A & $\Delta \mathrm{Y} 144$ & 76.91 & $\begin{array}{l}\text { Decrease infectivity, antibody } \\
\text { escape }^{19}\end{array}$ \\
\hline $\begin{array}{c}N S P 1 \\
(O R F 1 a b)\end{array}$ & $\mathrm{C} 335 \mathrm{~T}$ & CGC to $\mathbf{T G C}$ & $\mathrm{R} 24 \mathrm{C}$ & 0.38 & N/A \\
\hline$N S P 2$ & G1210T & ATG to ATT & M135I & 0.01 & N/A \\
\hline \multirow[t]{3}{*}{$(O R F 1 a b)$} & $\mathrm{C} 1059 \mathrm{~T}$ & $\mathrm{ACC}$ to $\mathrm{ATC}$ & $\mathrm{T} 85 \mathrm{I}$ & 13.95 & N/A \\
\hline & $\mathrm{T} 1947 \mathrm{C}$ & GTT to GCT & V381A & 1.08 & N/A \\
\hline & $\mathrm{C} 2453 \mathrm{~T}$ & CTC to TTC & L550F & 5.93 & N/A \\
\hline NSP3 & C7926T & GCA to GTA & A1736V & 0.12 & N/A \\
\hline \multirow[t]{7}{*}{$(O R F 1 a b)$} & $\mathrm{T} 7767 \mathrm{C}$ & $\mathrm{ATC}$ to $\mathrm{ACC}$ & $\mathrm{I} 1683 \mathrm{~T}$ & 0.19 & N/A \\
\hline & $\mathrm{C} 5622 \mathrm{~T}$ & CCT to CTT & P968L & 0.09 & N/A \\
\hline & G8371T & CAG to CAT & Q1884H & 0.05 & N/A \\
\hline & $\mathrm{C} 4002 \mathrm{~T}$ & ACT to ATT & T428I & 0.44 & N/A \\
\hline & C5388A & GCT to GAT & A890D & 76.25 & N/A \\
\hline & G8083A & ATG to ATA & M1788I & 0.68 & N/A \\
\hline & $\mathrm{C} 3602 \mathrm{~T}$ & CAC to TAC & $\mathrm{H} 295 \mathrm{Y}$ & 0.30 & N/A \\
\hline NSP4 & C9246T & GCT to GTT & $\mathrm{A} 231 \mathrm{~V}$ & 0.12 & N/A \\
\hline$(O R F 1 a b)$ & G9526T & ATG to ATT & M324I & 0.14 & N/A \\
\hline NSP5 & A10323G & AAG to AGG & K90R & 3.07 & N/A \\
\hline \multirow[t]{2}{*}{$(O R F 1 a b)$} & G10097A & GGT to AGT & G15S & 0.35 & N/A \\
\hline & $\mathrm{C} 10319 \mathrm{~T}$ & CTT to TTT & $\mathrm{L} 89 \mathrm{~F}$ & 1.44 & N/A \\
\hline NSP6 & $\mathrm{C} 11109 \mathrm{~T}$ & GCT to GTT & A46V & 0.15 & N/A \\
\hline \multirow[t]{8}{*}{$(O R F 1 a b)$} & C11396T & CTT to TTT & L142F & 0.02 & N/A \\
\hline & G11083T & TTG to TTT & L37F & 1.26 & N/A \\
\hline & $\mathrm{C} 11195 \mathrm{~T}$ & CTT to TTT & $\mathrm{L} 75 \mathrm{~F}$ & 0.13 & N/A \\
\hline & G11230T & ATG to ATT & M86I & 0.03 & N/A \\
\hline & G11801A & GGT to AGT & G277S & 0.07 & N/A \\
\hline & G11132T & GCT to TCT & A54S & 0.02 & N/A \\
\hline & $11288-11296$ & N/A & $\Delta \mathrm{S} 106 / \Delta \mathrm{G} 3$ & 87.61 & N/A \\
\hline & del & & $676 / \Delta F 3677$ & & \\
\hline
\end{tabular}


medRxiv preprint doi: https://doi.org/10.1101/2021.03.06.21252994; this version posted May 15, 2021. The copyright holder for this preprint (which was not certified by peer review) is the author/funder, who has granted medRxiv a license to display the preprint in perpetuity.

It is made available under a CC-BY 4.0 International license.

Castonguay et al., 2021

\begin{tabular}{|c|c|c|c|c|c|}
\hline NSP7 & G12067T & ATG to ATT & M75I & 0.15 & N/A \\
\hline$(O R F 1 a b)$ & C11916T & TCA to TTA & $\mathrm{S} 25 \mathrm{~L}$ & 0.10 & N/A \\
\hline $\begin{array}{c}\text { NSP9 } \\
(O R F 1 a b)\end{array}$ & G12988T & ATG to ATT & M101I & 0.23 & N/A \\
\hline \multirow[t]{6}{*}{$\begin{array}{c}\text { NSP12 } \\
(\text { ORF } 1 a b)\end{array}$} & C14408T & CCT to CTT & P323L & 99.49 & $\begin{array}{l}\text { Improves processivity by } \\
\text { interaction with NSP8 } 55\end{array}$ \\
\hline & G15766T & GTG to TTG & V776L & 0.14 & N/A \\
\hline & G13993T & GCT to TCT & A185S & 0.09 & N/A \\
\hline & G15598A & GTC to ATC & V720I & 0.17 & N/A \\
\hline & G14202T & GAG to GAT & E254D & 0.01 & N/A \\
\hline & C13730T & GCT to GTT & A97V & 0.35 & N/A \\
\hline \multirow{8}{*}{$\begin{array}{c}\text { NSP13 } \\
(O R F 1 a b)\end{array}$} & $\mathrm{C} 16289 \mathrm{~T}$ & GCT to GTT & A18V & 0.03 & N/A \\
\hline & G17019T & GAG to GAT & E261D & 0.22 & N/A \\
\hline & $\mathrm{C} 17104 \mathrm{~T}$ & CAT to TAT & H290Y & 0.23 & N/A \\
\hline & $\mathrm{C} 17747 \mathrm{~T}$ & CCT to CTT & P504L & 0.07 & $\begin{array}{c}\text { Increases hydrophobicity of } 2 \mathrm{~A} \\
\text { domain }^{56}\end{array}$ \\
\hline & $\mathrm{C} 17639 \mathrm{~T}$ & TCA to TTA & S468L & 0.02 & N/A \\
\hline & A17615G & AAG to AGG & K460R & 15.82 & N/A \\
\hline & A16889G & AAA to AGA & K218R & 0.08 & N/A \\
\hline & G18028T & GCA to TCA & A598S & 0.26 & N/A \\
\hline \multirow{4}{*}{$\begin{array}{c}\text { NSP14 } \\
(\text { ORFlab) }\end{array}$} & C18998T & GCA to GTA & A320V & 0.01 & N/A \\
\hline & $\mathrm{C} 18568 \mathrm{~T}$ & CTC to TTC & L177F & 0.22 & N/A \\
\hline & G19542T & ATG to ATT & M501I & 0.21 & N/A \\
\hline & A18424G & AAT to GAT & N129D & 1.37 & N/A \\
\hline $\begin{array}{c}\text { NSP15 } \\
(\text { ORF } 1 a b)\end{array}$ & C19718T & ACA to ATA & T33I & 0.06 & N/A \\
\hline \multirow{2}{*}{$\begin{array}{l}\text { NSP16 } \\
(\text { ORF1ab) }\end{array}$} & A21137G & AAG to AGG & K160R & 4.69 & N/A \\
\hline & A21390G & TTA to TTG & $\mathrm{R} 216 \mathrm{C}$ & 1.30 & N/A \\
\hline \multirow[t]{20}{*}{$N$} & C28932T & GCT to GTT & A220V & 0.38 & N/A \\
\hline & G28580T & GAT to TAT & D103Y & 0.02 & N/A \\
\hline & G28883C & GGA to $\mathbf{C G A}$ & G204R & 75.15 & Destabilizes $\mathrm{N}$ protein ${ }^{57}$ \\
\hline & $\mathrm{C} 28311 \mathrm{~T}$ & $\mathrm{CCC}$ to $\mathrm{CTC}$ & P13L & 2.00 & N/A \\
\hline & C28869T & CCA to CTA & P199L & 5.55 & N/A \\
\hline & G28882A & $\mathrm{AGC}$ to $\mathrm{AAA}$ & R203K & 81.96 & Destabilizes $N$ protein ${ }^{57}$ \\
\hline & C28883A & $\mathrm{AGC}$ to $\mathrm{AAA}$ & R203K & 81.96 & Destabilizes N protein ${ }^{57}$ \\
\hline & $\mathrm{C} 28854 \mathrm{~T}$ & TCA to TTA & S194L & 0.33 & Destabilizes $N$ protein ${ }^{57}$ \\
\hline & C28977T & TCT to TTT & $\mathrm{S} 235 \mathrm{~F}$ & 76.34 & N/A \\
\hline & G28280C & GAT to CTA & D3L & 75.53 & N/A \\
\hline & A28281T & GAT to CTA & D3L & 75.53 & N/A \\
\hline & T28282A & GAT to CTA & D3L & 75.53 & N/A \\
\hline & G28975C & ATG to ATC & M234I & 7.58 & N/A \\
\hline & $\mathrm{C} 28472 \mathrm{~T}$ & CCT to TCT & P67S & 1.38 & N/A \\
\hline & G29399A & GCT to ACT & A376T & 0.09 & N/A \\
\hline & C29366T & CCA to TCA & P365S & 0.15 & N/A \\
\hline & G29402T & GAT to TAT & D377Y & 1.61 & N/A \\
\hline & $\mathrm{C} 28887 \mathrm{~T}$ & ACT to ATT & T205I & 7.00 & N/A \\
\hline & C29466T & GCA to GTA & A398V & 0.51 & N/A \\
\hline & A26530G & GAT to GGT & D3G & 0.01 & N/A \\
\hline & C27046T & ACG to ATG & $\mathrm{T} 175 \mathrm{M}$ & 0.02 & N/A \\
\hline$N S 3$ & G25907T & GGT to GTT & G172V & 1.41 & N/A \\
\hline$(O R F 3 a)$ & G25617T & AAG to AAT & $\mathrm{K} 75 \mathrm{~N}$ & 0.02 & N/A \\
\hline
\end{tabular}

Genome Evolution of SARS-CoV-2 
medRxiv preprint doi: https://doi.org/10.1101/2021.03.06.21252994; this version posted May 15, 2021. The copyright holder for this preprint (which was not certified by peer review) is the author/funder, who has granted medRxiv a license to display the preprint in perpetuity.

It is made available under a CC-BY 4.0 International license.

Castonguay et al., 2021

Genome Evolution of SARS-CoV-2

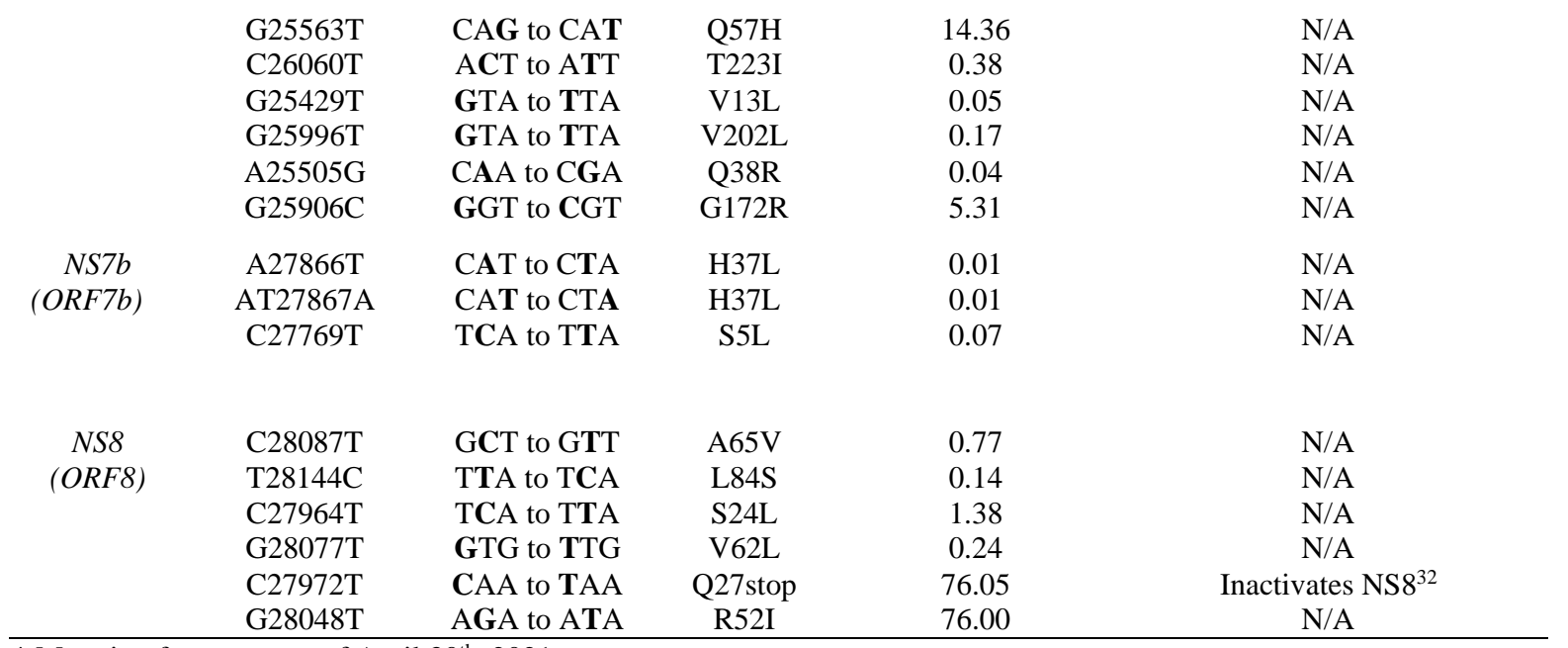

* Mutation frequency as of April 30 $0^{\text {th }}, 2021$. 
medRxiv preprint doi: https://doi.org/10.1101/2021.03.06.21252994; this version posted May 15, 2021. The copyright holder for this preprint (which was not certified by peer review) is the author/funder, who has granted medRxiv a license to display the preprint in perpetuity.

It is made available under a CC-BY 4.0 International license.

Castonguay et al., 2021

Genome Evolution of SARS-CoV-2

Table 2: Synonymous, non-synonymous and deletion mutations in the B.1.1.7 variant

\begin{tabular}{|c|c|c|c|c|c|c|c|}
\hline Variant & $\begin{array}{c}\text { Protein } \\
\text { (Gene) }\end{array}$ & $\begin{array}{l}\text { Genome } \\
\text { Nucleotide } \\
\text { Mutation }\end{array}$ & $\begin{array}{c}\text { S or } \\
\text { NS }\end{array}$ & $\begin{array}{c}\text { AA } \\
\text { mutation }^{20}\end{array}$ & Domain & $\begin{array}{c}\text { Frequency* } \\
(\%)\end{array}$ & Effect \\
\hline \multirow[t]{26}{*}{ B.1.1.7 } & $\begin{array}{c}\text { NSP2 } \\
(\text { ORF1ab) }\end{array}$ & C913T & $S$ & & & N/A & N/A \\
\hline & $\begin{array}{c}N S P 3 \\
(O R F 1 a b)\end{array}$ & C3267T & NS & T183I & & 76.14 & N/A \\
\hline & & C5388A & NS & A890D & & 76.24 & N/A \\
\hline & & C5986T & $\mathrm{S}$ & & & N/A & N/A \\
\hline & & T6954C & NS & $\mathrm{I} 1412 \mathrm{~T}$ & & 75.21 & N/A \\
\hline & $\begin{array}{c}\text { NSP6 } \\
\text { (ORF1ab) }\end{array}$ & $\begin{array}{l}\text { 11288- } \\
11296 \mathrm{del}\end{array}$ & NS & $\begin{array}{c}\Delta \mathrm{S} 106 / \\
\Delta \mathrm{G} 107 / \Delta \mathrm{F} 108\end{array}$ & & 87.61 & N/A \\
\hline & NSP12 & $\mathrm{C} 14676 \mathrm{~T}$ & S & & & N/A & N/A \\
\hline & (סח & $\mathrm{C} 15279 \mathrm{~T}$ & S & & & N/A & N/A \\
\hline & $\begin{array}{l}\text { NSP13 } \\
(\text { ORF1ab) }\end{array}$ & $\mathrm{C} 16176 \mathrm{~T}$ & $S$ & & & N/A & N/A \\
\hline & $S$ & $\begin{array}{l}21765- \\
21770 \text { del }\end{array}$ & NS & $\Delta \mathrm{H} 69 / \Delta \mathrm{V} 70$ & NTD & 75.13 & Antibody escape ${ }^{53}$ \\
\hline & & $\begin{array}{l}\text { 21991- } \\
\text { 21993del }\end{array}$ & NS & $\Delta \mathrm{Y} 144$ & NTD & 76.91 & $\begin{array}{l}\text { Decreases infectivity, } \\
\text { Antibody escape }{ }^{19}\end{array}$ \\
\hline & & A23063T & NS & N501Y & RBD & 80.16 & $\begin{array}{c}\text { Increases affinity for } \\
\text { hACE2 } 2^{51}\end{array}$ \\
\hline & & C23271A & NS & A570D & SD1 & 76.30 & \\
\hline & & A23403G & NS & D614G & SD2 & 99.29 & $\begin{array}{l}\text { Moderate increase in } \\
\text { transmissibility } 19,51\end{array}$ \\
\hline & & C23709A & NS & P681H & SD2 & 79.18 & N/A \\
\hline & & $\mathrm{C} 23709 \mathrm{~T}$ & NS & T716I & & 75.37 & N/A \\
\hline & & T24506G & NS & S982A & HR1 & 74.61 & N/A \\
\hline & & G24914C & NS & D1118H & & 74.82 & N/A \\
\hline & $\begin{array}{c}N S 8 \\
(O R F 8)\end{array}$ & $\mathrm{C} 27972 \mathrm{~T}$ & NS & Q27stop & & 76.05 & Inactivation of $\mathrm{NS}^{32}$ \\
\hline & & G28048T & NS & R52I & & 76.00 & N/A \\
\hline & & $\mathrm{A} 28111 \mathrm{G}$ & NS & Y73C & & 76.07 & N/A \\
\hline & $M$ & $\mathrm{~T} 26801 \mathrm{C}$ & S & & & N/A & N/A \\
\hline & $N$ & G28280C & NS & D3L & & 75.53 & N/A \\
\hline & & A28281T & NS & D3L & & 75.53 & N/A \\
\hline & & T28282A & NS & D3L & & 75.53 & N/A \\
\hline & & C28977T & NS & S235F & & 76.34 & N/A \\
\hline
\end{tabular}

\footnotetext{
$*$ Mutation frequency as of April 30 2021.
} 
medRxiv preprint doi: https://doi.org/10.1101/2021.03.06.21252994; this version posted May 15, 2021. The copyright holder for this preprint (which was not certified by peer review) is the author/funder, who has granted medRxiv a license to display the preprint in perpetuity.

It is made available under a CC-BY 4.0 International license .

Castonguay et al., 2021

Genome Evolution of SARS-CoV-2

Table 3: Synonymous, non-synonymous mutations and deletions in the B.1.351 variant

\begin{tabular}{|c|c|c|c|c|c|c|c|}
\hline Variant & $\begin{array}{l}\text { Protein } \\
\text { (Gene) }\end{array}$ & $\begin{array}{c}\text { Genome } \\
\text { Nucleotide } \\
\text { Mutation }^{22}\end{array}$ & $\begin{array}{l}\text { S or } \\
\text { NS }\end{array}$ & A.A mutation & Domain & $\begin{array}{l}\text { Frequency } \\
\quad *(\%)\end{array}$ & Effect \\
\hline \multirow[t]{22}{*}{ B.1.351 } & $\overline{5 '-U T R}$ & G174T & $\mathbf{S}$ & & & N/A & $\mathrm{N} / \mathrm{A}$ \\
\hline & $N S P 2$ & $\mathrm{C} 1059 \mathrm{~T}$ & NS & T85I & & 13.95 & N/A \\
\hline & (ORFlab) & A2692T & $\mathrm{S}$ & & & N/A & N/A \\
\hline & $\begin{array}{c}\text { NSP3 } \\
(\text { ORFlab) }\end{array}$ & G5230T & NS & K837N & & 1.41 & N/A \\
\hline & $\begin{array}{c}\text { NSP5 } \\
(\text { ORFlab) }\end{array}$ & A10323G & NS & K90R & & 3.07 & N/A \\
\hline & $\begin{array}{l}\text { NSP12 } \\
(\text { ORF1ab) }\end{array}$ & $\mathrm{C} 14925 \mathrm{~T}$ & $S$ & & & N/A & N/A \\
\hline & $S$ & $\mathrm{C} 21614 \mathrm{~T}$ & NS & L18F & NTD & 4.11 & N/A \\
\hline & & A21801C & NS & D80A & NTD & 0.50 & N/A \\
\hline & & A22206G & NS & D215G & NTD & 0.51 & N/A \\
\hline & & $\begin{array}{c}\text { 22286- } \\
\text { 22294del }\end{array}$ & NS & $\Delta \mathrm{L} 242 / \Delta \mathrm{A} 243 / \Delta \mathrm{L} 244$ & NTD & 0.51 & Antibody escape ${ }^{58}$ \\
\hline & & G22299T & NS & R246I & NTD & 0.004 & Antibody escape ${ }^{58}$ \\
\hline & & G22813T & NS & $\mathrm{K} 417 \mathrm{~N}$ & RBD & 0.51 & Antibody escape ${ }^{24}$ \\
\hline & & G23012A & NS & E484K & RBD & 3.51 & Antibody escape $^{33,53}$ \\
\hline & & A23063T & NS & N501Y & RBD & 80.16 & $\begin{array}{l}\text { Increases affinity for } \\
\qquad \mathrm{hACE} 2^{51}\end{array}$ \\
\hline & & A23403G & NS & D614G & SD2 & 99.29 & $\begin{array}{l}\text { Moderate increase in } \\
\text { transmissbility } 19,53\end{array}$ \\
\hline & & G23664T & NS & A701V & $\mathrm{S} 1 / \mathrm{S} 2-\mathrm{S} 2$ & 2.15 & N/A \\
\hline & NS3 & G25563T & NS & Q57H & & 14.36 & N/A \\
\hline & $(O R F 3 a)$ & $\mathrm{C} 25904 \mathrm{~T}$ & NS & S171L & & 1.77 & N/A \\
\hline & E & $\mathrm{C} 26456 \mathrm{~T}$ & NS & P71L & & 1.42 & N/A \\
\hline & $M$ & $\mathrm{C} 26645 \mathrm{~T}$ & $S$ & & & & N/A \\
\hline & $\begin{array}{l}N S 7 a \\
(\text { ORF7a) }\end{array}$ & $\mathrm{T} 27504 \mathrm{C}$ & $S$ & & & & N/A \\
\hline & $N$ & C28887T & NS & T205I & & 7.00 & N/A \\
\hline
\end{tabular}

* Mutation frequency as of April 30 2021. 
medRxiv preprint doi: https://doi.org/10.1101/2021.03.06.21252994; this version posted May 15, 2021. The copyright holder for this preprint (which was not certified by peer review) is the author/funder, who has granted medRxiv a license to display the preprint in perpetuity.

It is made available under a CC-BY 4.0 International license.

Castonguay et al., 2021

Genome Evolution of SARS-CoV-2

Table 4: Synonymous, non-synonymous and deletions in the P.1 variant.

\begin{tabular}{|c|c|c|c|c|c|c|c|}
\hline Variant & $\begin{array}{l}\text { Protein } \\
\text { (Gene) }\end{array}$ & $\begin{array}{c}\text { Genome } \\
\text { Nucleotide } \\
\text { Mutation }^{23}\end{array}$ & $\begin{array}{l}\text { S or } \\
\text { NS }\end{array}$ & $\begin{array}{c}\text { A.A } \\
\text { mutation }\end{array}$ & Domain & $\begin{array}{c}\text { Frequency* } \\
(\%)\end{array}$ & Effect \\
\hline \multirow[t]{23}{*}{ P.1 } & $\begin{array}{c}N S P 2 \\
\text { (ORF1 }\end{array}$ & $\begin{array}{c}\mathrm{T} 733 \mathrm{C} \\
\end{array}$ & $\mathrm{S}$ & & & N/A & N/A \\
\hline & & & & & & & \\
\hline & $\begin{array}{c}N S P 3 \\
\text { (ORFIab) }\end{array}$ & C3828T & NS & $\begin{array}{l}\text { S370L } \\
\text { K9770 }\end{array}$ & & 3.09 & N/A \\
\hline & (ORFlab) & A5648C & NS & K977Q & & 3.00 & N/A \\
\hline & $\begin{array}{c}\text { NSP6 } \\
(\text { ORFlab) }\end{array}$ & $\begin{array}{l}\text { 11288- } \\
11296 \mathrm{del}\end{array}$ & NS & $\begin{array}{c}\Delta \mathrm{S} 106 / \\
\Delta \mathrm{G} 107 / \Delta \mathrm{F} \\
108\end{array}$ & & 87.61 & N/A \\
\hline & $\begin{array}{c}\text { NSP9 } \\
(\text { ORFlab) }\end{array}$ & $\mathrm{C} 12778 \mathrm{~T}$ & $\mathrm{~S}$ & & & N/A & N/A \\
\hline & $\begin{array}{l}\text { NSP12 } \\
(\text { ORFlab) }\end{array}$ & $\mathrm{C} 13860 \mathrm{~T}$ & $\mathrm{~S}$ & & & N/A & N/A \\
\hline & $\begin{array}{l}\text { NSP13 } \\
\text { (ORF1ab) }\end{array}$ & G17259T & NS & E341D & & 2.97 & N/A \\
\hline & $S$ & C21614T & NS & L18F & NTD & 4.11 & N/A \\
\hline & & C21621A & NS & $\mathrm{T} 20 \mathrm{~N}$ & NTD & 2.77 & N/A \\
\hline & & $\mathrm{C} 21638 \mathrm{~T}$ & NS & P26S & NTD & 3.01 & N/A \\
\hline & & G21974T & NS & D138Y & NTD & 2.95 & N/A \\
\hline & & G22132T & NS & R190S & NTD & 2.71 & N/A \\
\hline & & A22812C & NS & K417T & RBD & 2.88 & Antibody escape ${ }^{39}$ \\
\hline & & G23012A & NS & E484K & RBD & 3.51 & Antibody escape ${ }^{33,53}$ \\
\hline & & A $23063 \mathrm{~T}$ & NS & N501Y & RBD & 80.16 & $\begin{array}{c}\text { Increase affinity for } \\
\text { hACE } 2^{53}\end{array}$ \\
\hline & & A23403G & NS & D614G & SD2 & 99.29 & $\begin{array}{l}\text { Moderate increase in } \\
\text { transmissibility } 19,53\end{array}$ \\
\hline & & $\mathrm{C} 23525 \mathrm{~T}$ & NS & H655Y & SD2 & 3.16 & N/A \\
\hline & & C24642T & NS & T1027I & $\mathrm{S} 2$ & 2.79 & N/A \\
\hline & & G25088T & NS & V1176F & S2 & 2.79 & N/A \\
\hline & NS8 & G28167A & NS & E92K & & 2.96 & N/A \\
\hline & (ORF8) & $\begin{array}{l}\text { Ins28269- } \\
28273\end{array}$ & $\mathrm{~S}$ & & & N/A & N/A \\
\hline & $N$ & $\mathrm{C} 28512 \mathrm{G}$ & NS & P80R & & 2.94 & N/A \\
\hline
\end{tabular}

* Mutation frequency as of April 30"th 2021. 
medRxiv preprint doi: https://doi.org/10.1101/2021.03.06.21252994; this version posted May 15, 2021. The copyright holder for this preprint (which was not certified by peer review) is the author/funder, who has granted medRxiv a license to display the preprint in perpetuity.

It is made available under a CC-BY 4.0 International license .

Castonguay et al., 2021

Genome Evolution of SARS-CoV-2

Table 5: Efficacy of Vaccines Against SARS-CoV-2 Variants

\begin{tabular}{ccccc}
\hline Vaccine & $\begin{array}{c}\text { hCoV- } \\
\text { 19/Whan/WIV- } \\
\text { 4/2019 }\end{array}$ & B.1.1.7 & B.1.351 & P.1 \\
\hline Pfizer-BioNTech & $95.0 \%^{40}$ & $95.3 \% \%^{31,37}$ & $75.0 \%^{37}$ & N/A \\
Moderna & $94.1 \%^{41}$ & N/A & N/A & N/A \\
Oxford-AstraZeneca & $70.4 \%^{42}$ & $70.4 \%^{34}$ & $10 \%^{36}$ & N/A \\
Johnson \& Johnson & $66 \%^{43}$ & N/A & $52.0 \%$ and $64.0 \%$ & $66 \%^{43}$ \\
& & & $(14 \text { and } 28 \text { days })^{43}$ & \\
Novavax & $96 \%^{44}$ & $86 \%^{44}$ & $51 \%^{44}$ & \\
\hline
\end{tabular}

Table 6: Resistance of SARS-CoV-2 Variants to Vaccine-Induced Antibody Neutralization

\begin{tabular}{cccc}
\hline Vaccine & \multicolumn{3}{c}{ Fold Reduction in Neutralization } \\
& B.1.1.7 & B.1.351 & P.1 \\
\hline Pfizer-BioNTech & ${ }^{a} 2.1^{39}$ & ${ }^{\mathrm{a}}(34.5-42.4)^{39}$ & ${ }^{\mathrm{a}} 6.7^{39}$ \\
Moderna & ${ }^{\mathrm{a}} 2.3^{39}$ & ${ }^{\mathrm{a}}(19.2-27.7)^{39}$ & ${ }^{\mathrm{a}} 4.5^{39}$ \\
Oxford-AstraZeneca & $\mathrm{b} 2.5^{45}$ & $\mathrm{~b}^{39} .0^{46}$ & $\mathrm{~b} 2.6^{47}$ \\
Johnson \& Johnson & N/A & N/A & N/A \\
Novavax & $\mathrm{a}(0.85 \text { to } 20)^{48}$ & ${ }^{\mathrm{a}} 13.1^{49}$ & $\mathrm{~N}$ \\
\hline
\end{tabular}

${ }^{a}$ Pseudotyped virus neutralization assay.

${ }^{\mathrm{b}}$ Live virus neutralization assay. 
medRxiv preprint doi: https://doi.org/10.1101/2021.03.06.21252994; this version posted May 15, 2021. The copyright holder for this preprint

(which was not certified by peer review) is the author/funder, who has granted medRxiv a license to display the preprint in perpetuity.

It is made available under a CC-BY 4.0 International license .

Castonguay et al., $2021 \quad$ Genome Evolution of SARS-CoV-2

\section{FIGURE LEGENDS}

Figure 1: Variations in mutations and mutation frequencies in SARS-CoV-2 genes. The occurrence and frequency of mutations in various SARS-CoV-2 genes are presented for the period between December 2019 to January $1^{\text {st }}, 2021$. Plotted are mutations that reached at least a $1 \%$ worldwide frequency. SARSCoV-2 genes are represented with the function of the genes in parentheses. A) Genes with $<10$ mutations. B) Genes with >10 mutations. Graphs were generated using RStudio. *overlapping curves

Figure 2: Geographic location and timeline of dominant mutations in NSP12, S, and N genes. A) Frequency of S protein mutations with corresponding geographic maps. B) Frequency of RdRp mutations with corresponding geographic maps. C) Frequency of Nucleoprotein mutations with corresponding geographic maps. D) Timeline of the appearance of mutations reaching a frequency higher than $50 \%$ worldwide between December, 2019 and April, 2021. For the geomaps: a low frequency of reported cases of the mutations is represented in white, while higher frequencies are represented from pink to red, and grey represents no data. All maps were taken from GISAID. Graphs were generated using RStudio and Biorender. *overlapping curves

Figure 3: Structural rendering of the most frequent mutations in the $S$ protein. A) Surface representation of hACE2 (yellow) in complex with S protein trimers illustrated in grey, blue, and magenta. Interactions of high frequency mutations are presented as follows: B) A222V, C) S477N, D) L18F, E) D614G in the open conformation and F) D614G in the closed conformation. Reference sequence residues are illustrated in green, and the mutated amino acid is represented in purple. The red markers illustrate the steric clash when the mutations are inserted into the structure. Graphs were generated using PyMOL.

Figure 4: Worldwide frequency of B.1.1.7, B.1.351, P.1 and D614G variants. Database variants frequency were analyzed from December, 2019 to April $30^{\text {th }}$, 2021. hCoV-19/Wuhan is the original reference strain and hCoV-19/D614G is the current reference strain containing the D614G mutation in the S protein. B.1.1.7, B.1.353, and P.1 represent the UK, South African, and Brazilian variants. *overlapping curves.

Figure 5: Analysis of mutations in the B.1.1.7 variant. A) Mutation map of the spike protein of B.1.1.7. B) Structural representation of spike with ACE2. B.1.1.7 S protein mutations are presented in in red. NTD (green), RBD (blue), SD1 (purple), SD2 (light blue), and S2 (magenta) are illustrated. The other S protein 
medRxiv preprint doi: https://doi.org/10.1101/2021.03.06.21252994; this version posted May 15, 2021. The copyright holder for this preprint (which was not certified by peer review) is the author/funder, who has granted medRxiv a license to display the preprint in perpetuity. It is made available under a CC-BY 4.0 International license .

Castonguay et al., 2021

Genome Evolution of SARS-CoV-2

monomers are displayed in grey and white. C) Frequency of the mutations in the S protein, B.1.1.7 variant from December, 2019 to April 30 ${ }^{\text {th }}, 2021$. D) Interaction of the N501Y (red) mutation in the RBD (blue) of S protein with hACE2 (yellow). The dash lines indicate interactions with adjacent residues. E) Genome of the SARS-CoV-2 B.1.1.7 variant with identified nucleotide substitutions and deletions. Graphs were generated using Biorender, PyMOL, and RStudio. *overlapping curves.

Figure 6: Analysis of mutations in the B.1.351 variant. A) Mutation map of the spike protein of B.1.351. B) Structural representation of spike with ACE2. B.1.352 S protein mutations are presented in orange. NTD (green), RBD (blue), SD1 (purple), SD2 (light blue), and S2 (magenta) are illustrated. The other S protein monomers are illustrated in grey and white. C) Frequency of the mutations in the S protein B.1.351 variant from December, 2019 to April $30^{\text {th }}$, 2021. Interaction of D) 417N with C102 Nab (green), E) 484K with C121 Nab (light pink), and F) 501Y with hACE2 (yellow). The mutant residues are illustrated in orange, and the dashed lines represent interactions with adjacent residues. G) Genome of the SARS-CoV-2 B.1.351 variant with identified nucleotide substitutions or deletions. Graphs were generated using Biorender, PyMOL, and RStudio. *overlapping curves.

Figure 7: Analysis of mutations in the P.1 variant. A) Mutation map of the spike protein of P.1. B) Structural representation of spike with ACE2. P.1 S protein mutations are presented in black. NTD (green), RBD (blue), SD1 (purple), SD2 (light blue), and S2 (magenta) are illustrated. The other S protein monomers are illustrated in grey and white. C) Frequency of P.1 variant S protein mutations from December 2019 to April 30 ${ }^{\text {th }} 2021$. Interaction of D) 417T with C102 Nab (green), E) 484K with C121 Nab (light pink), and F) $501 \mathrm{Y}$ with hACE2 (yellow). The mutations are coloured in black and interaction with adjacent residues are demonstrated by dashed lines. G) Genome of the SARS-CoV-2 P.1 variant with identified nucleotides substitution, deletions, and insertions. Figures were generated using Biorender, PyMOL and RStudio. *overlapping curves.

Figure 8: Interactions of K417, E484, and N501 of the $S$ protein with neutralizing antibodies and hACE2. A) Interaction of K417 (blue) with C102 Nab (green) residues. B) Interaction of E484 (blue) with C121 Nab (light pink). C) Interaction of N501 (blue) with hACE2 (yellow) Dashes lines indicate interactions between residues. The graphs were generated using PyMOL. 
medRxiv preprint doi: https://doi.org/10.1101/2021.03.06.21252994; this version posted May 15, 2021. The copyright holder for this preprint (which was not certified by peer review) is the author/funder, who has granted medRxiv a license to display the preprint in perpetuity.

It is made available under a CC-BY 4.0 International license.

Figure 1
A

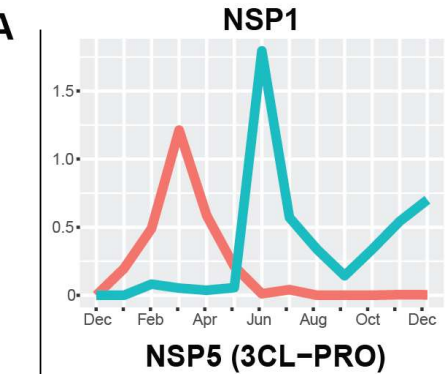

NSP15(NendoU)

B
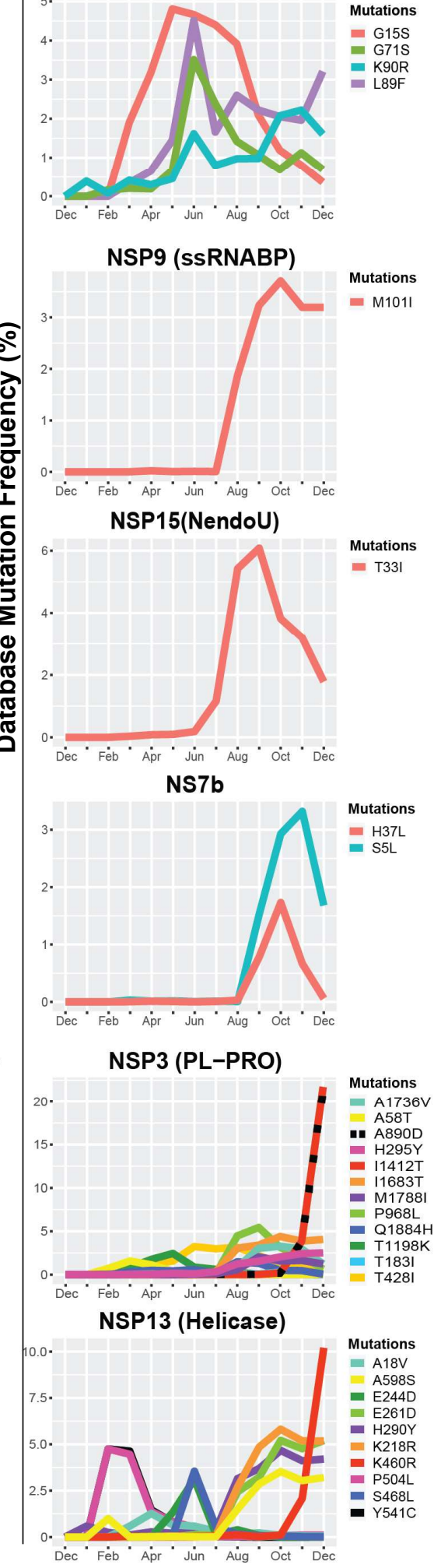

Mutations

M101I

Mutations

- T33I

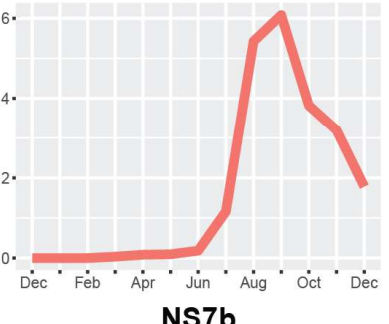

NS7b

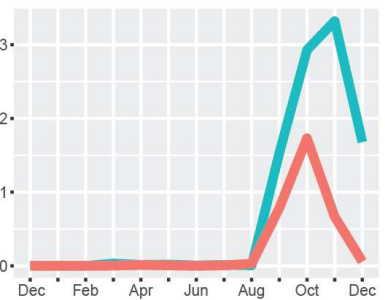

Mutations

$\mathrm{H} 37 \mathrm{~L}$
$\mathrm{~S} 5 \mathrm{~L}$

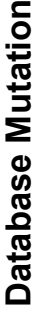

Déc" Féb" Ápr "Jün "Aug " Oct" Déc
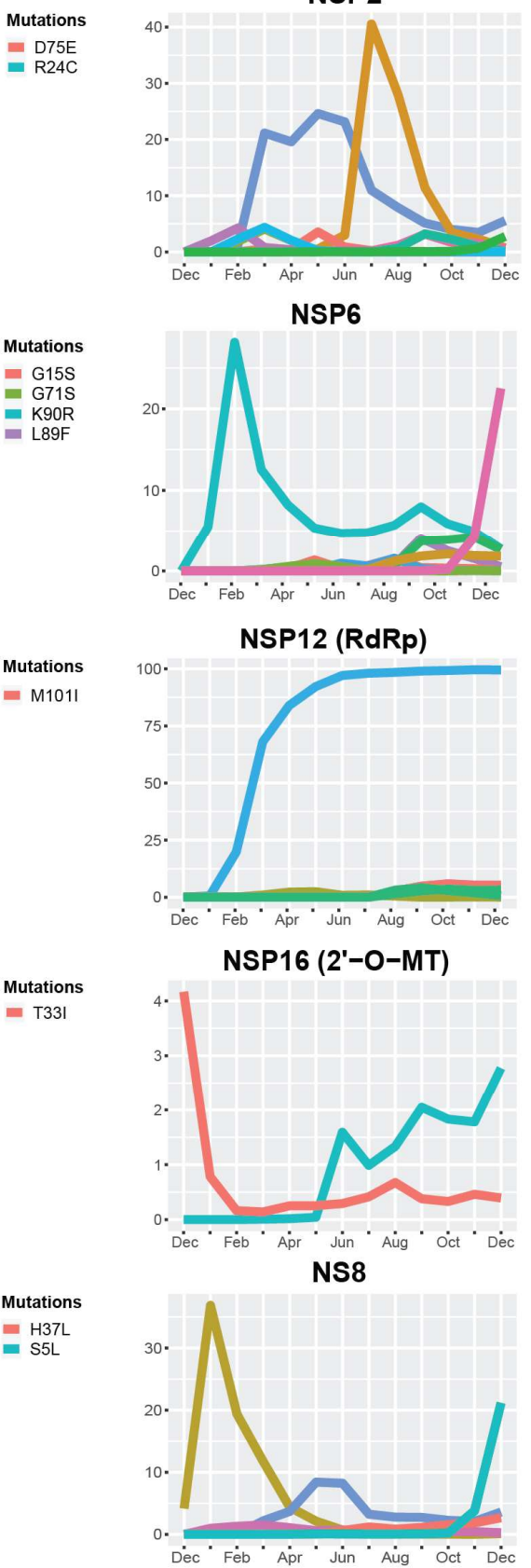

S (SPIKE)
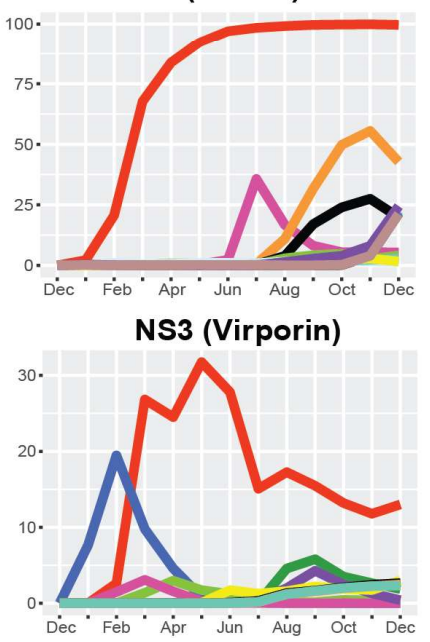

NSP2

NSP4

Mutations - F10L I120F
I559V I559V
- L550F M135I - P585S T85I
V198I V381A
V381

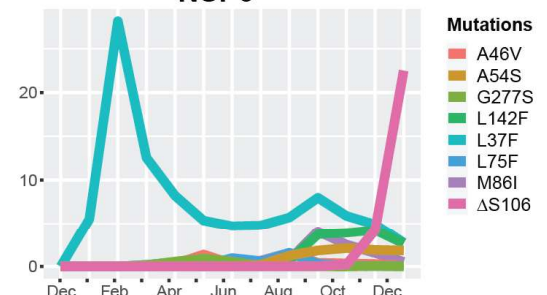
NSP12 (RdRp)

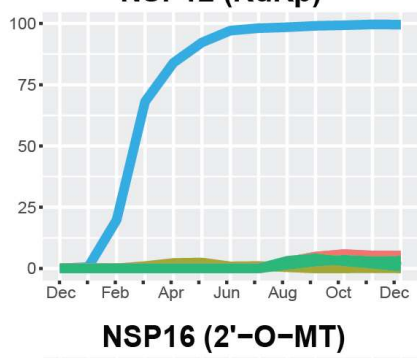

Mutations

A185S

A97V

- P323L

V776L

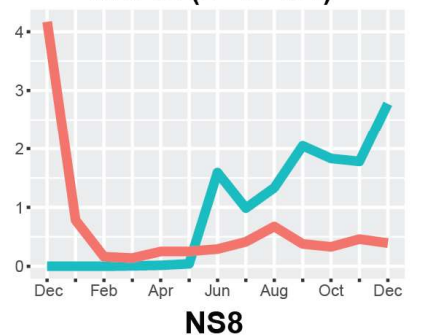

Mutations

K160R
R216C

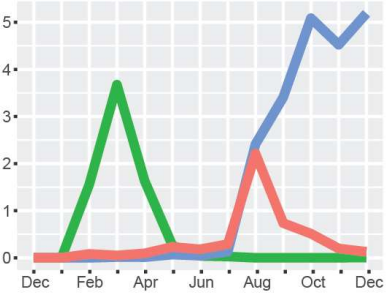

NSP7

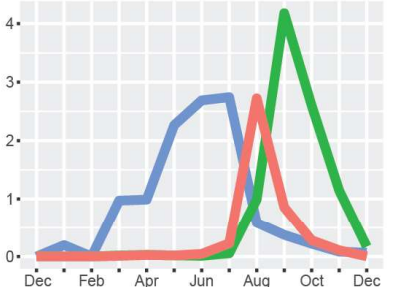

Mutations

- M3I

$M 75 \mid$
$-S 25 L$

Mutations

- A65V

- L84S

- Q27stop

- R52I

- S24L

- V62L

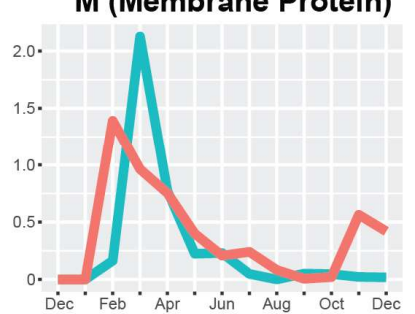

Mutations

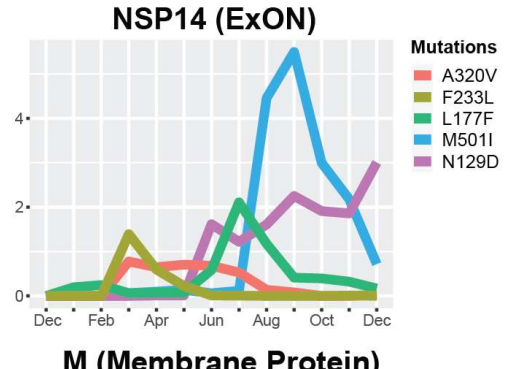

D3G
$=$ T175M

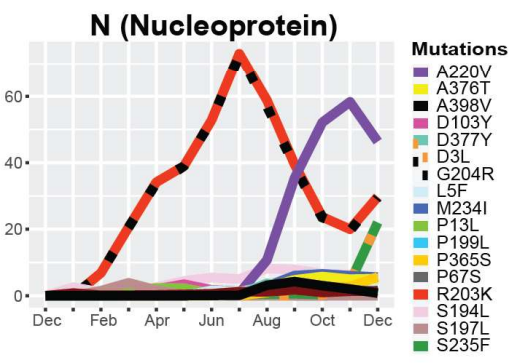


medRxiv preprint doi: https://doi.org/10.1101/2021.03.06.21252994; this version posted May 15, 2021. The copyright holder for this preprint (which was not certified by peer review) is the author/funder, who has granted medRxiv a license to display the preprint in perpetuity.

\section{It is made available under a CC-BY 4.0 International license .}

\section{Figure 2}

A

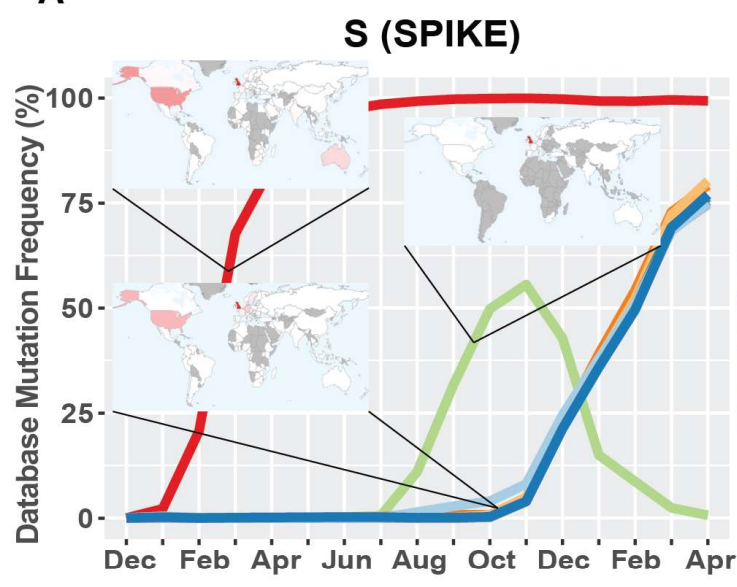

B

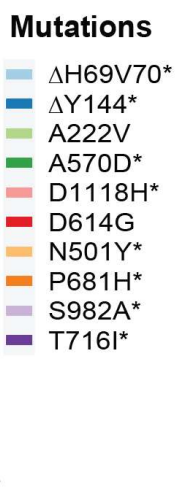

NSP12 (RdRp)

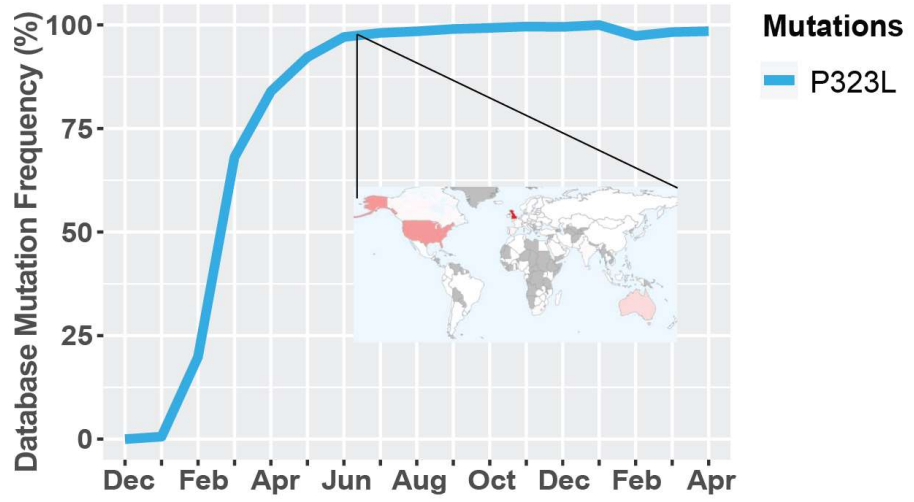

C

N (Nucleoprotein)

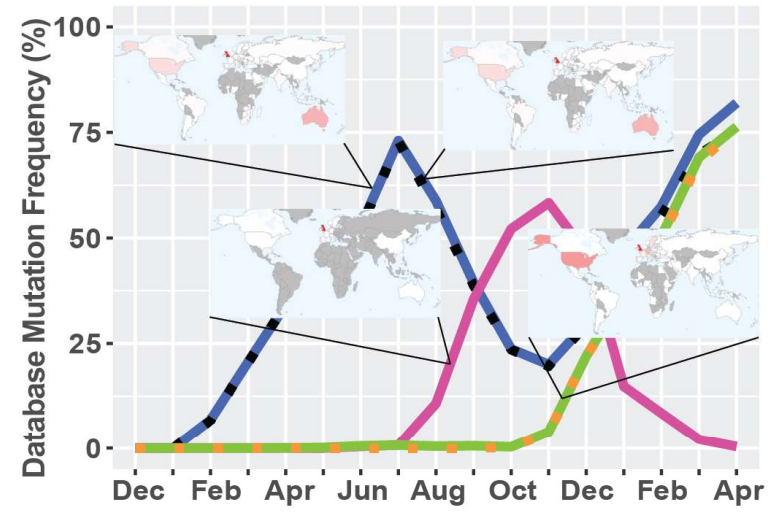

Mutations

- $\mathrm{A} 22 \mathrm{OV}$
$=\mathrm{D} 3 \mathrm{~L}$
- - $\mathrm{G} 204 \mathrm{R}$
- $\mathrm{R} 203 \mathrm{~K}$
$=\mathrm{S} 235 \mathrm{~F}$

D

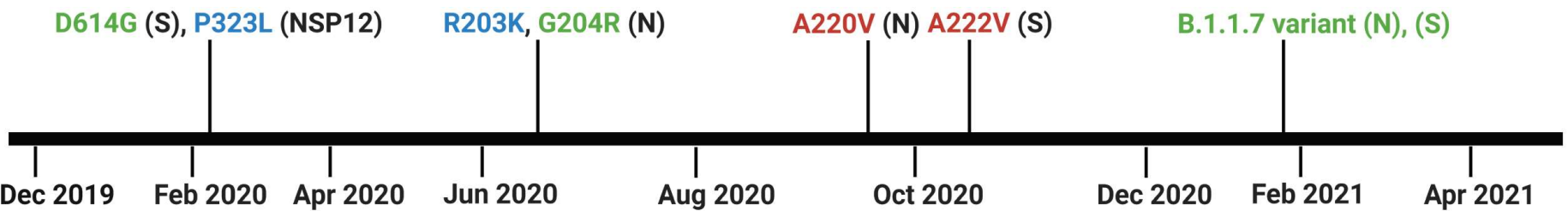


medRxiv preprint doi: https://doi.org/10.1101/2021.03.06.21252994; this version posted May 15,2021 . The copyright holder for this preprint (which was not certified by peer review) is the author/funder, who has granted medRxiv a license to display the preprint in perpetuity.

It is made available under a CC-BY 4.0 International license .

\section{Figure 3}

A

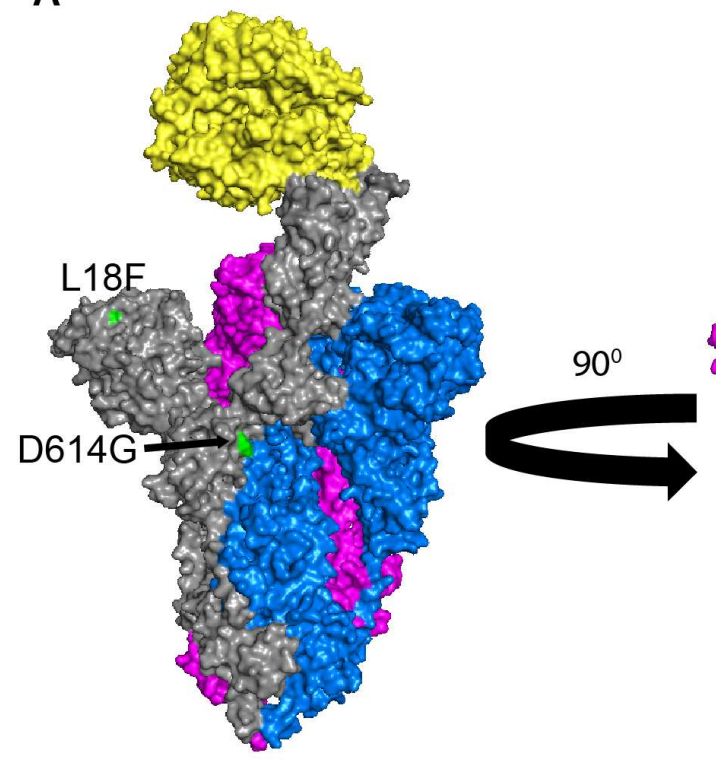

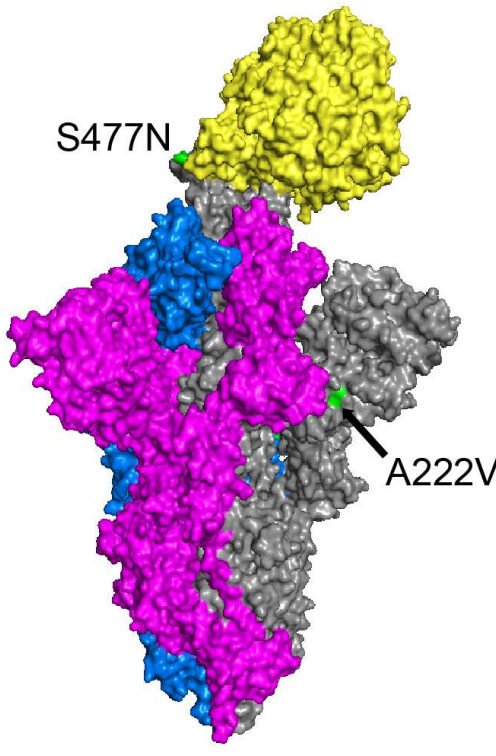

B
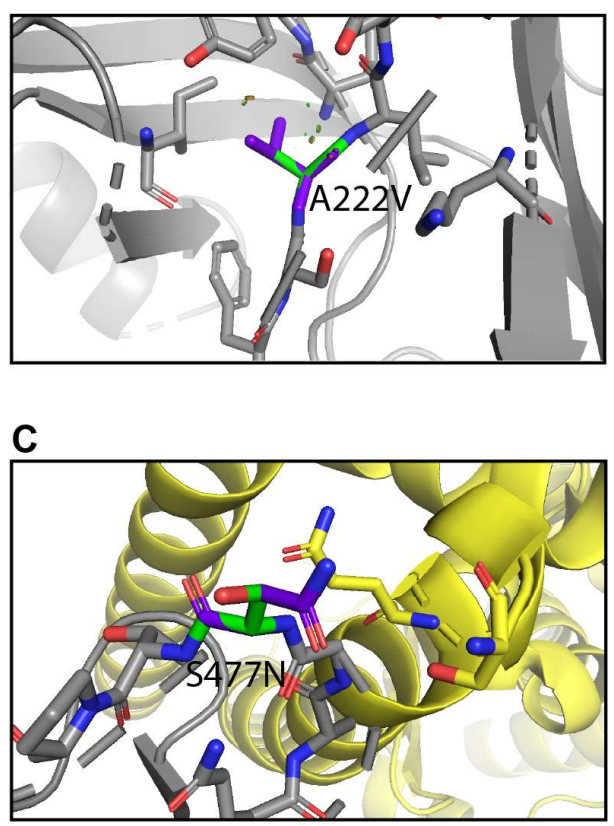

D

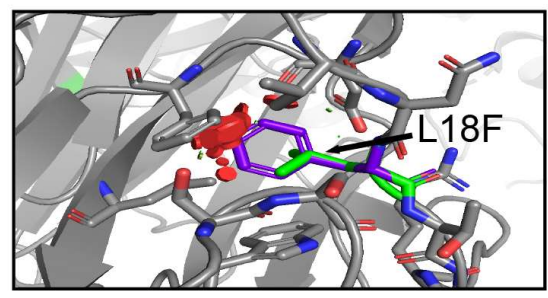

E

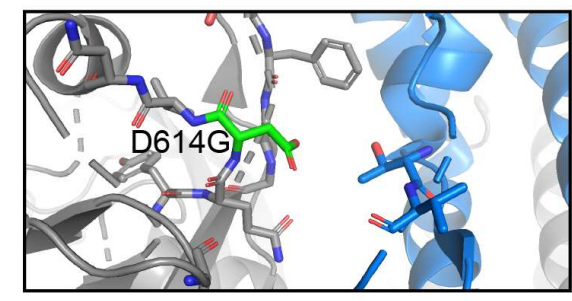

F

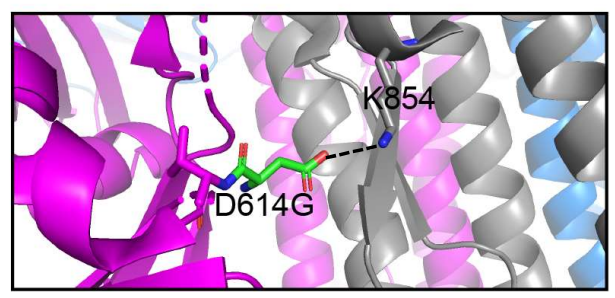


medRxiv preprint doi: https://doi.org/10.1101/2021.03.06.21252994; this version posted May 15, 2021. The copyright holder for this preprint (which was not certified by peer review) is the author/funder, who has granted medRxiv a license to display the preprint in perpetuity.

It is made available under a CC-BY 4.0 International license .

\section{Figure 4}

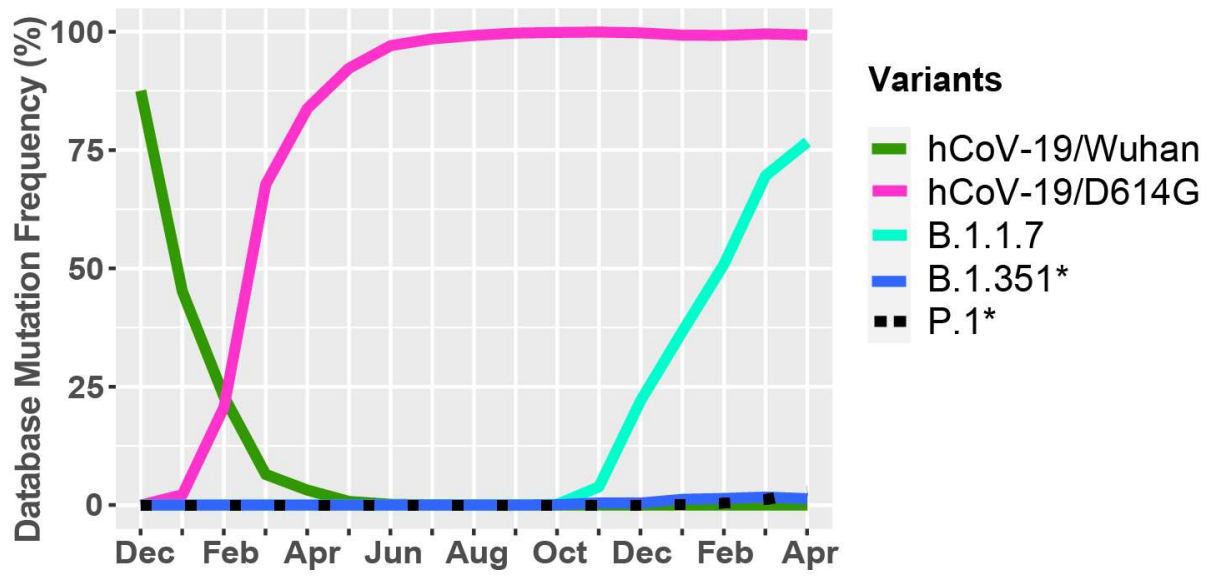


medRxiv preprint doi: https://doi.org/10.1101/2021.03.06.21252994; this version posted May 15, 2021. The copyright holder for this preprint (which was not certified by peer review) is the author/funder, who has granted medRxiv a license to display the preprint in perpetuity.

It is made available under a CC-BY 4.0 International license.

Figure 5

A

B

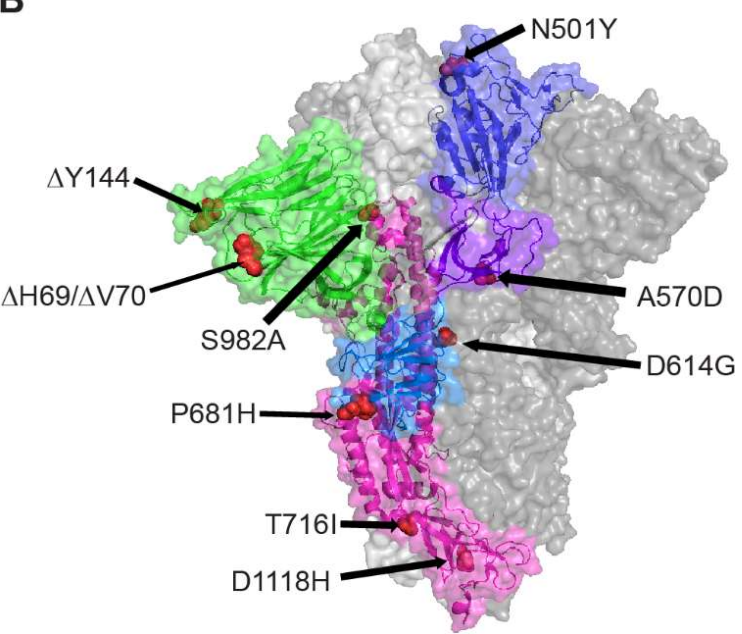

D

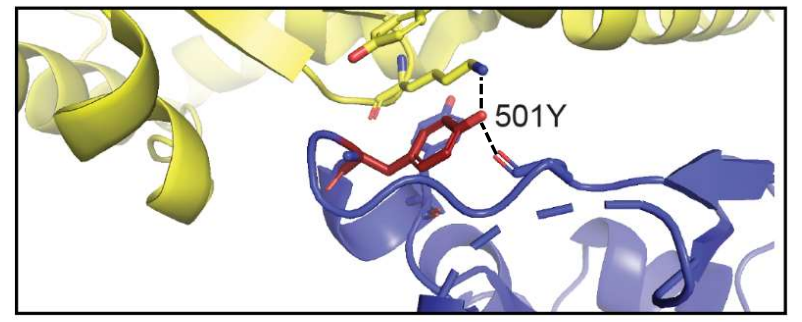

E

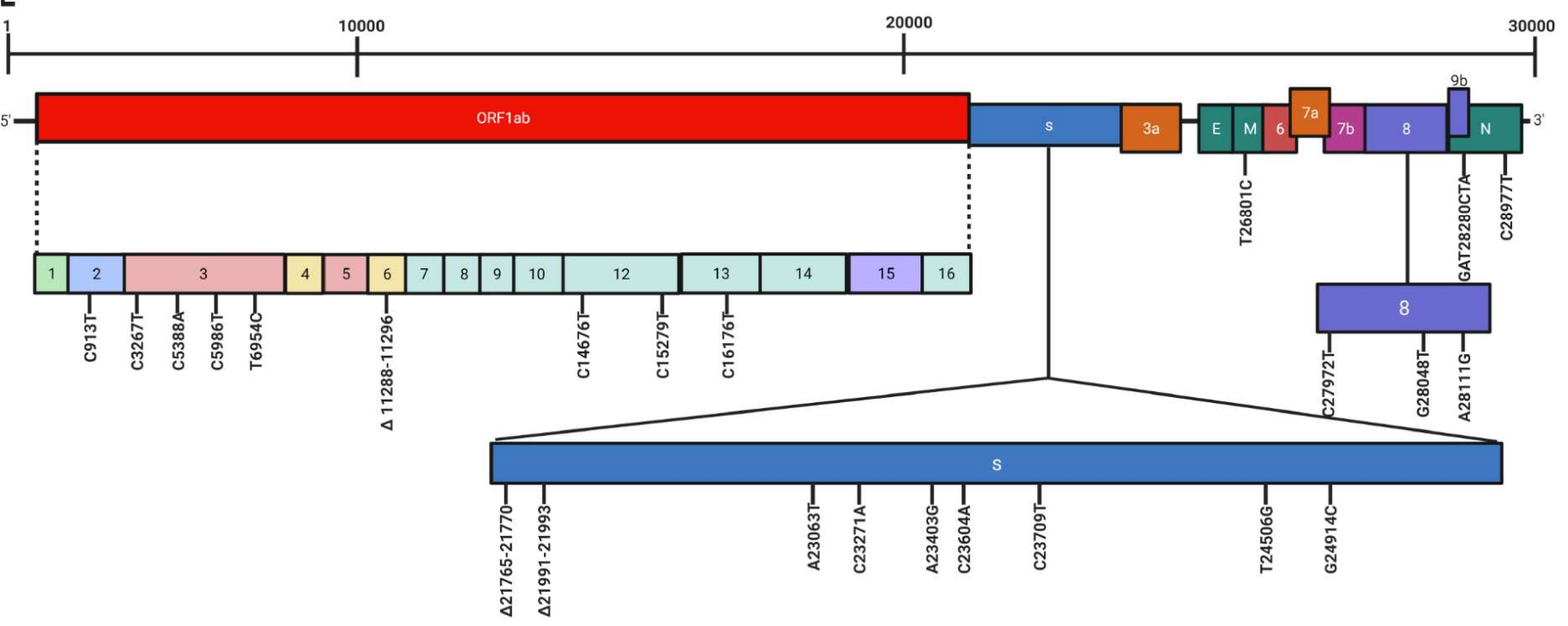

Mutations

- $\Delta \mathrm{H} 69 / \Delta \mathrm{V} 7 \mathrm{O}^{*}$

- $\Delta \mathrm{Y} 144^{*}$ A570D*

- $\mathrm{D} 1118 \mathrm{H}^{\star}$

- D614G

- N501Y*

- $\mathrm{P} 681 \mathrm{H}^{\star}$

- S982A*

- T716I*
B.1.1.7

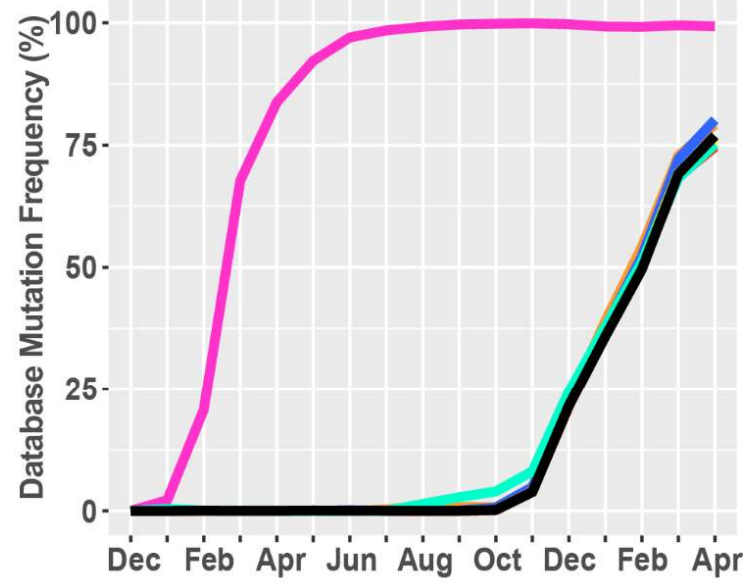


medRxiv preprint doi: https://doi.org/10.1101/2021.03.06.21252994; this version posted May 15, 2021. The copyright holder for this preprint (which was not certified by peer review) is the author/funder, who has granted medRxiv a license to display the preprint in perpetuity.

It is made available under a CC-BY 4.0 International license .

\section{Figure 6}

A

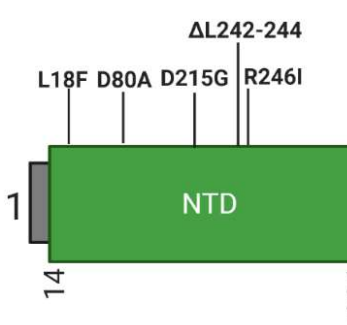

S1

B
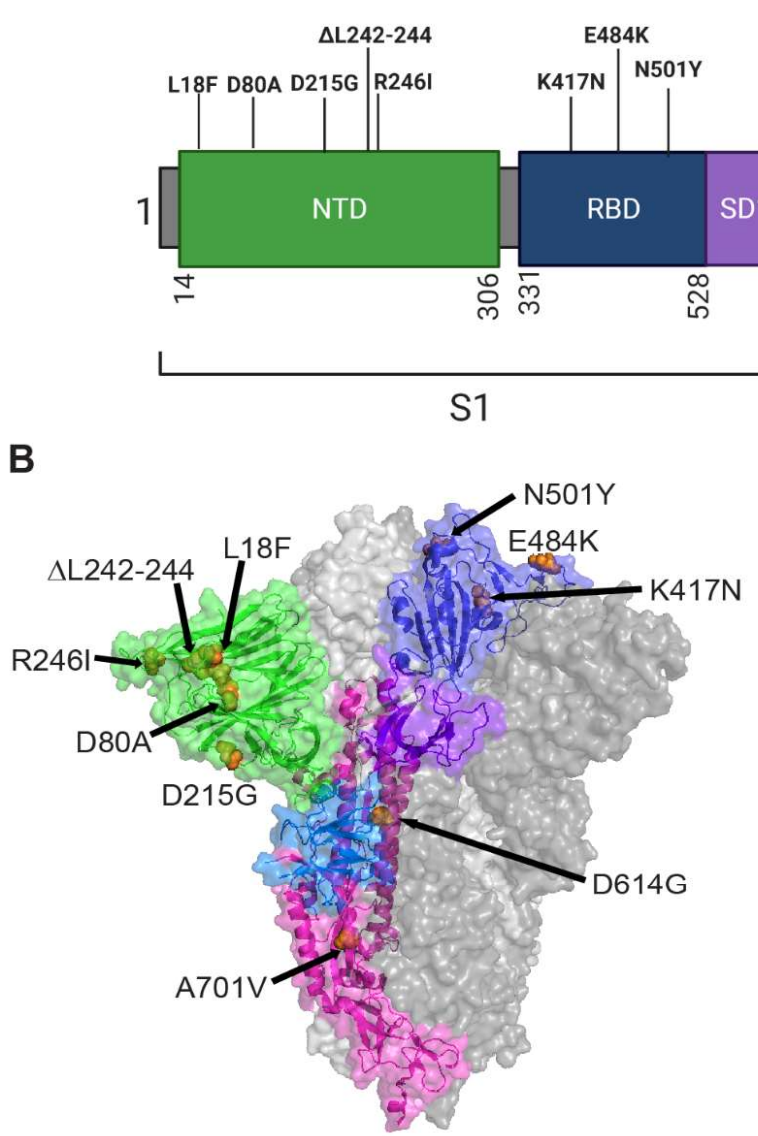

\section{B.1.351}

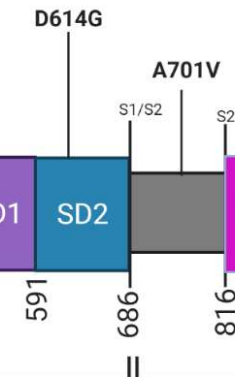

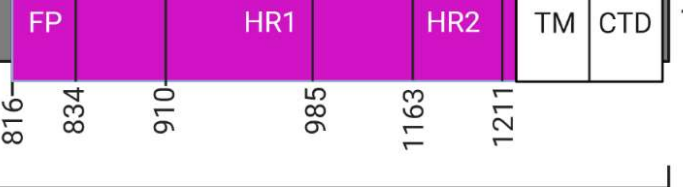

S2

C

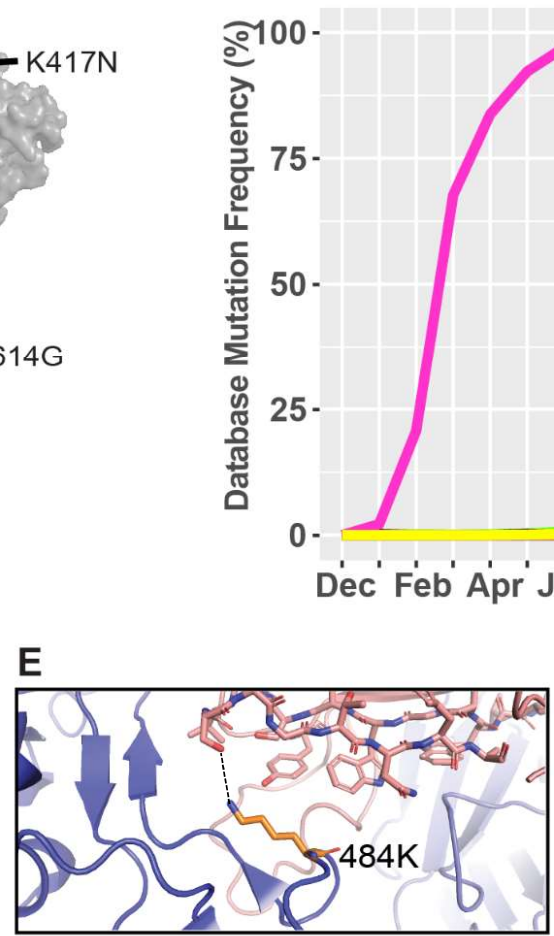

E
Mutations

- $\Delta \mathrm{L} 242-244^{*}$

- N501Y

- D215G*

- D614G

- D80A*

- E484K*

- K417N*

- L18F A701V*

- R246I*
D

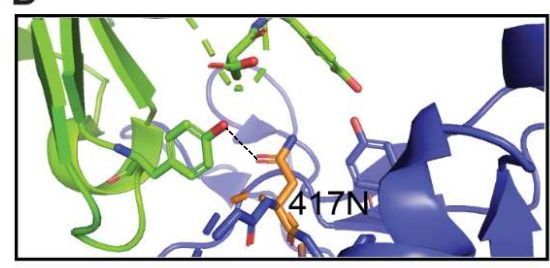

$\mathrm{F}$

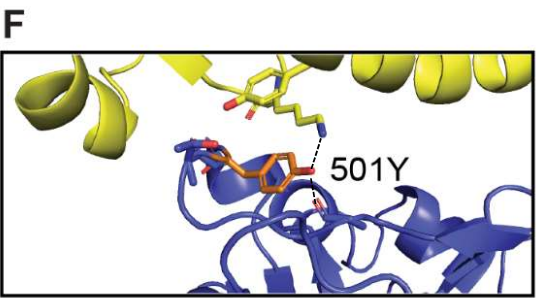

G

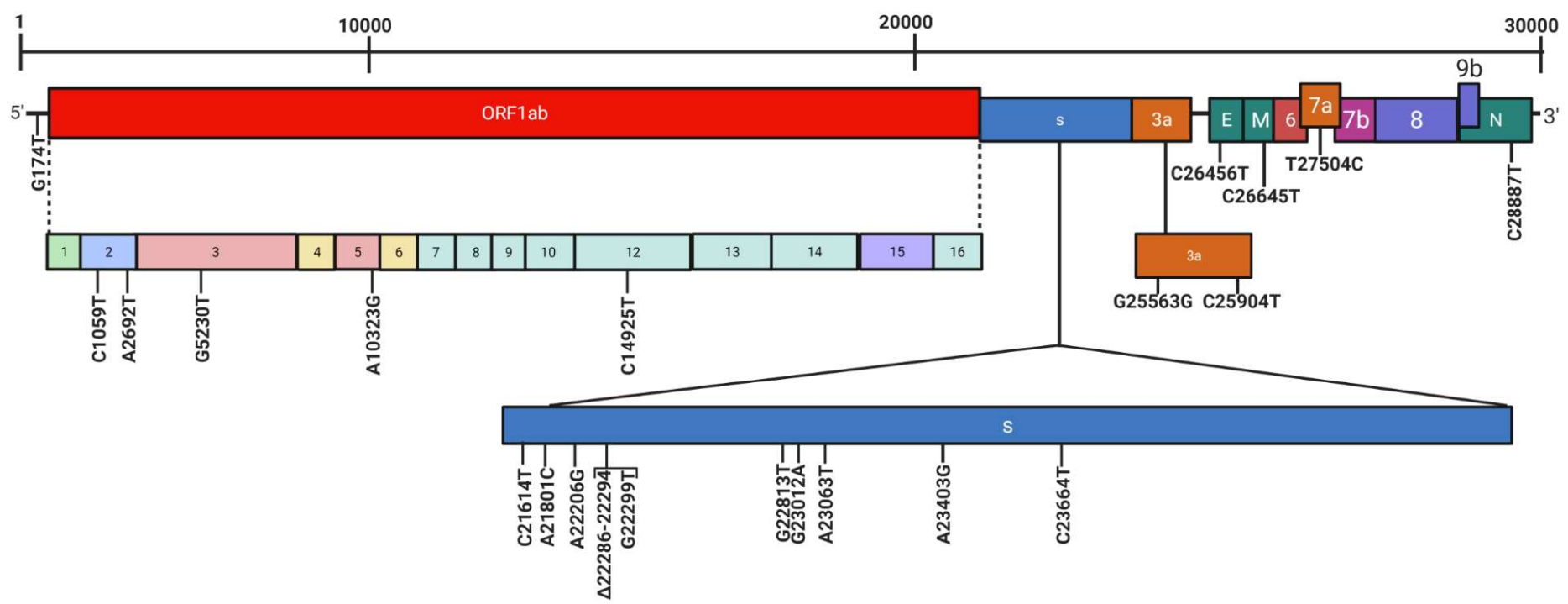


medRxiv preprint doi: https://doi.org/10.1101/2021.03.06.21252994; this version posted May 15, 2021. The copyright holder for this preprint (which was not certified by peer review) is the author/funder, who has granted medRxiv a license to display the preprint in perpetuity.

It is made available under a CC-BY 4.0 International license.

\section{Figure 7}

A

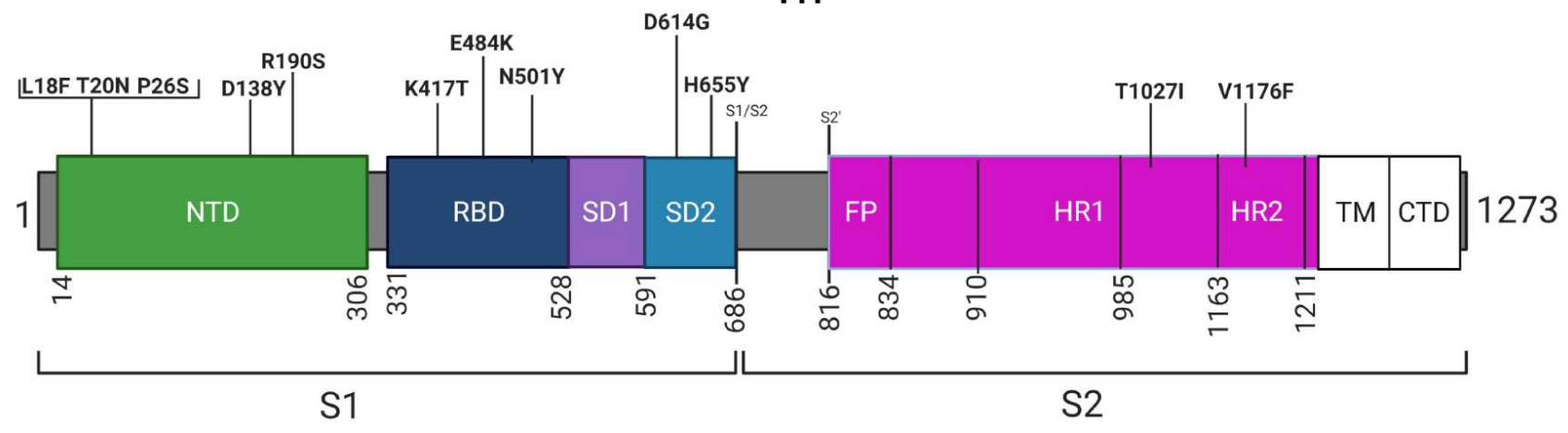

B

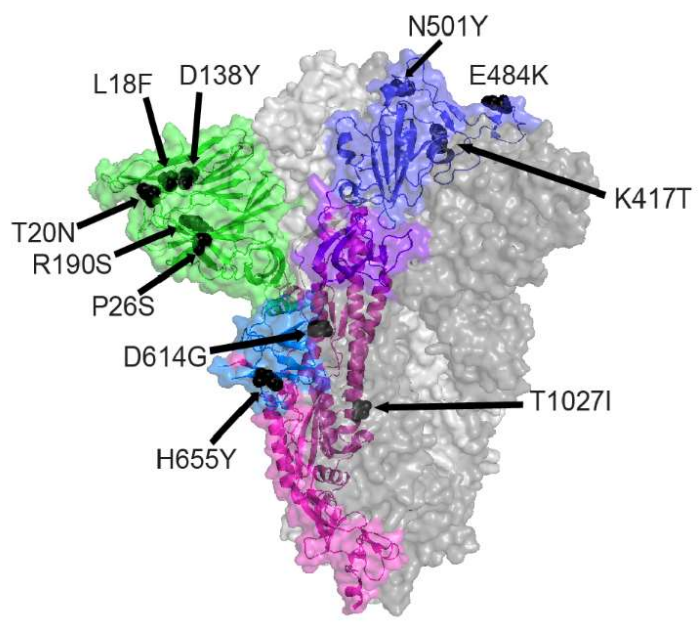

C

D

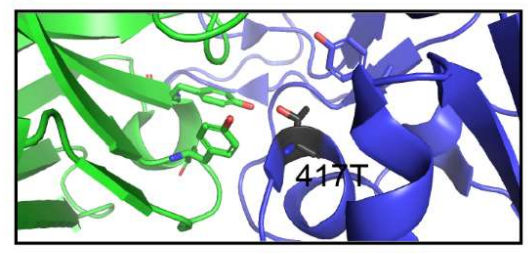

E

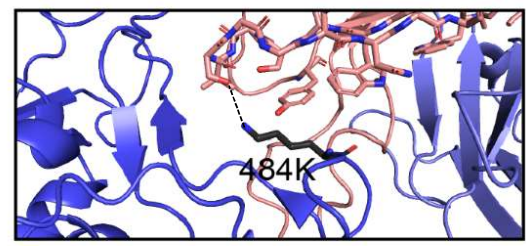

Mutations

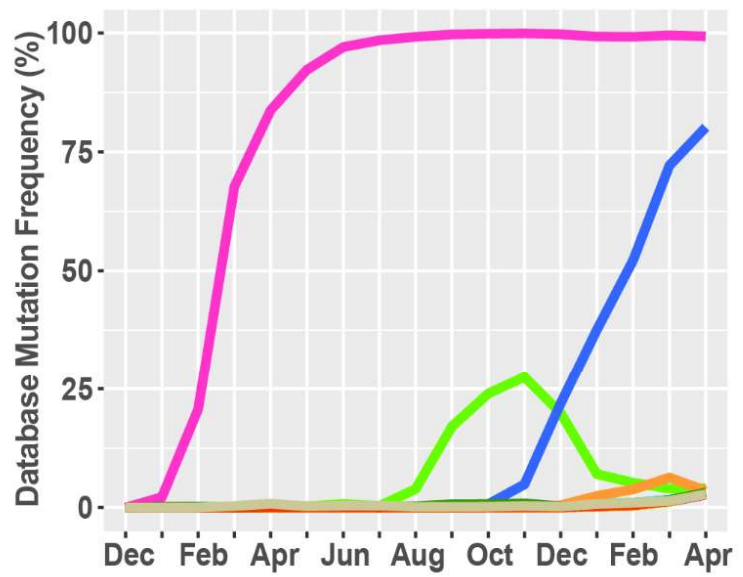

- D138Y*

- D614G

- E484K*

- H655Y*

K417T

$=\mathrm{L} 18 \mathrm{~F}$

- N501Y

- P26S*

- R190S*

- T1027/

- T20N*

- V1176F*

\section{G}
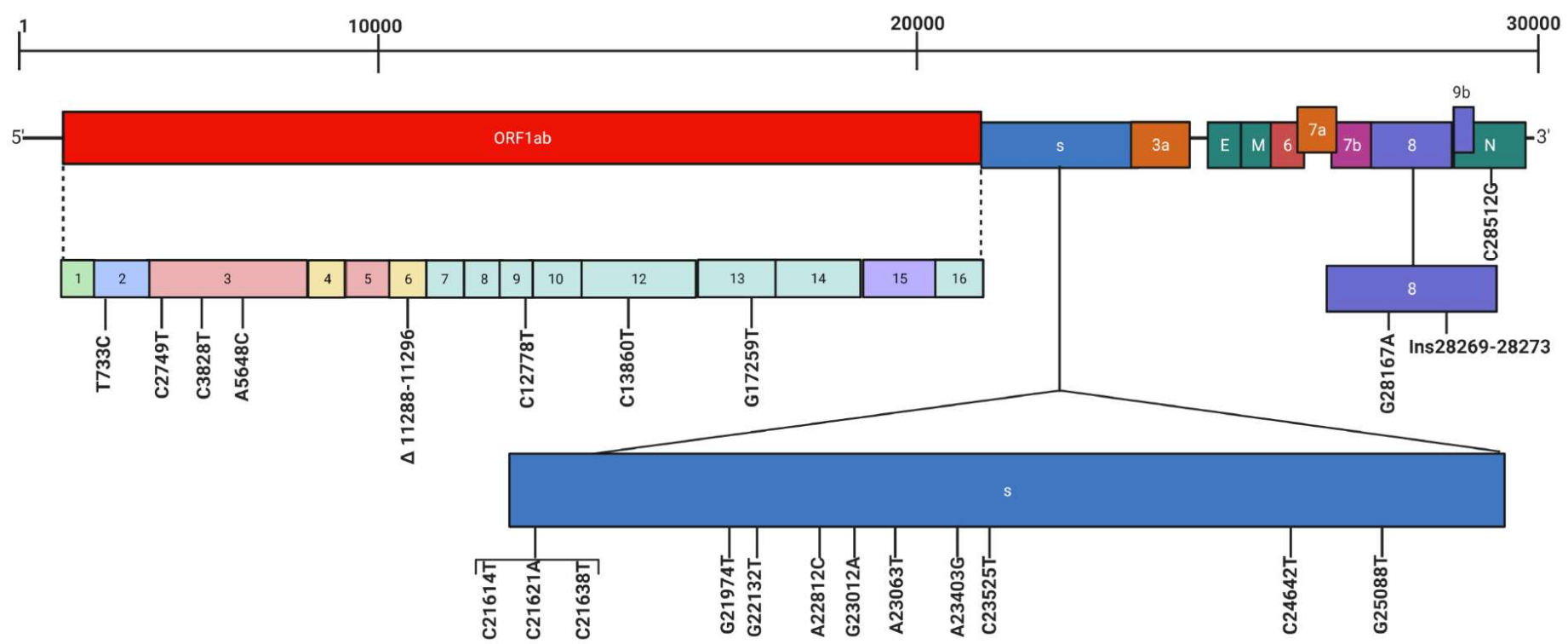
